Article

\title{
The Destructive/Non-Destructive Identification of Enameled Pottery, Glass Artifacts and Associated Pigments-A Brief Overview
}

\section{Philippe Colomban}

Laboratoire de Dynamique, Interaction et Réactivité - UMR7075, CNRS, Université Pierre-etMarie-Curie (UPMC), c49, 4 Place Jussieu, 75252 Paris Cedex 05, France;

E-Mail: philippe.colomban@ upmc.fr; Tel.: +33-144-272-787; Fax: +33-144-273-021

Received: 31 May 2013; in revised form: 3 July 2013 / Accepted: 5 July 2013 /

Published: 15 July 2013

\begin{abstract}
The birth of Chemistry can be found in two main practices: (i) the Arts $d u$ feu (ceramic and glass, metallurgy, i.e., inorganic and solid state chemistry) and (ii) the preparation of remedies, alcohols and perfumes, dyes, i.e., organic and liquid state chemistry). After a brief survey of the history of (glazed) pottery and (enameled) glass artifacts, the development of destructive and non-destructive analytical techniques during the last few centuries is reviewed. Emphasis is put on mobile non-destructive Raman microspectroscopy of pigments and their glass/glaze host matrices for chronological/technological expertise. The techniques of white opacification, blue, yellow, green, red, and black coloring, are used as examples to point out the interest of pigments as chronological/technological markers.
\end{abstract}

Keywords: cultural heritage; analysis; pottery; glass; enamel; pigments; spectroscopy

\section{Context}

The foundation of Chemistry is often related to the practice of ancient alchemists. However, the know-how required for the transformation of matter, the definition of Chemistry, can be found in two main practices: (i) the Arts $d u f e u$, i.e., the preparation of pottery, glass, and metal artifacts (and related techniques for the selection and preparation of the raw materials used: geology, mining...), in other words Inorganic and Solid State Chemistry; (ii) the preparation of remedies, alcohols and perfumes, pigments, dyes, and binding for frescoes, painting, and textiles, in other words Organic and Liquid 
State Chemistry [1-10]. The artifacts were prepared by craftsmen and/or artists, the distinction between them depending on cultural criteria more than technological ones.

For a long time, the search for quality and uniqueness had led masters to develop original techniques in order to make a reproduction by contemporary professionals difficult. Consequently, secrets and master-to-disciple oral transmission were the common law. Greek and Roman literature [11-15] remains the reference for the 'sciences' and technologies used in the Western and Mediterranean areas during many centuries, the relative part, transmitted by Western, Byzantine, Syriac, and Nestorian Monks [16], or by Arab scholars [6-8,10], being strongly debated [16]. The technical literature remained scarce until the $17^{\text {th }}$ century [6-10], the onset period of separation between practice and theory. That period also corresponds to the beginning of the large diffusion of book printing. At that time the separation between 'Chemistry', 'Physics', and Techniques is not yet consumed, and information on the 'Arts' of preparing materials and chemicals can be found in books dealing with Physique Experimentale [17,18], Elemens de Chymie Pratique [19], Histoire Naturelle [17,20], Physique [18], etc. or even Les Eléments de la Philosophie de l'Art du Feu ou Chemie (W. Davisson, the first Lecture in Chemistry given in France, published in Latin in 1655, in French in 1661, F. Piot, Paris), a typical title of the Alchemist' tradition.

Rare documents were, however, published before the Quattrocento and Renaissance [21-26] and the publication of information about Arts and Sciences truly started in Western Countries afterwards ([27-38] and references therein). The authors were generally scholars, not professionals of the techniques, which limited the precision and reliability of the information. Furthermore, the translation/identification of some terms (raw materials and ingredients, procedures, etc.) is very difficult because of the use of metaphoric expressions. The artifacts thus remain the only reliable source to retrieve the information about the technology used and the artisan(s) know-how.

Just like industry companies conduct re-engineering studies in order to identify the innovation of their competitors by dismounting/studying their products, we will show how this approach may be used to retrieve the ancient "secrets" of artists and masters to prepare pottery and glass artifacts. This experimental approach dates back to the $18^{\text {th }}$ century. The works of Macquer [19], Rouelle' brothers, Fourcroy, Réaumur [37], and Lewis [38] can be considered as very illustrative. The contribution of Hellot has been pointed out by the study of his manuscripts [39]. Then, Brongniard [40,41], Salvetat [42], Bontemps [43], Deck [44], Bastenaire-Daudenart [45], Jacquemart [46], etc. also performed comprehensive studies.

The high cultural value and uniqueness of many artifacts imply either a minimization of the (micro)sampling, or the use of non-destructive techniques. Furthermore, displacement of the masterpieces out of their secure locations (Museum, Collectors, and reserve rooms), or their dismounting (building part), is rarely authorized. We will discuss the identification of chronological/technological markers, namely the identification of chromophores, pigments and associated materials, and their glassy silicate matrix, used in ancient masterpieces such as pottery, enamels and enameled glass, pastels, drawings, paintings, etc. 


\section{Pottery and Glass Technology: A Brief Survey}

The production of pottery dates back to the Neolithic/Palaeolithic transition (>15,000 B.C. in Japan, Siberia and Africa) and requires heating above $600-650{ }^{\circ} \mathrm{C}$ to produce hard and robust artifacts by means of liquid phase sintering. The use and modeling of unfired clay pieces are much older, the first sculptures dating from the Palaeolithic ( 30,000 B.P.) [47-49]. However, it has been claimed that the Dolní Věstonice Venus sculpture (25-29,000 B.P., Czech Republic) had probably been heated [48]. Glass paste and glazed artifacts date back to $\sim 3000$ B.C. (Mesopotamia) [50]. The crude beads usually formed around a wire have blue and green colors suggesting that they were used to evoke lapis lazuli and turquoise stones. True glass artifacts date back to 1500-2000 B.C. (Egypt, Phoenicia, and Mesopotamia), colored/opacified with lead antimonate yellow, and calcium antimonate white [50]; heating at $\sim 900-1000{ }^{\circ} \mathrm{C}$ was achieved [51-54]. Large glass production stopped for a few hundred years around 1200 B.C., a period of wars accompanied by a trade disruption [50]. Similar interruptions occurred with the decline of the Roman Empire. Centuries before, Chinese Shang and Shang-Zhou proto-porcelains (3000-1500 B.C.) were fired at temperatures from $\sim 950{ }^{\circ} \mathrm{C}$ up to $\sim 1200-1250{ }^{\circ} \mathrm{C}$ [55].

Roman potters (sigillata) and glassmakers experimented mass production [56]. Chinese Eastern Han to Sui potters $\left(2^{\text {nd }}\right.$ B.C. $-7^{\text {th }}$ c. $)$ initiated the development of very high temperature firing technology: Yue wares were fired above $1300{ }^{\circ} \mathrm{C}$ [55]. White porcelains appeared during Sui and Tang Dynasties $\left(7^{\text {th }}-8^{\text {th }}\right.$ c.). At the same period the Islamic potters found how opacification by cassiterite tin oxide combined with low temperature firing could compete with high temperature fired porcelain to produce artifacts with complex depictions $[47,48,57,58]$. This innovation resulted from the imitation of the

three-color Chinese porcelain wares with lead-rich blue and green glaze dots deposited on a faience/terra cotta body covered with an alkaline glaze. The chemical reaction between the two glazes led to precipitation of white cassiterite [57]. This innovation was transmitted to Europe with the extension of the Islamic World (Ifriqaya $\left(7^{\text {th }}\right.$ c.), al Andalous $\left(8^{\text {th }}\right.$ c.), Sicilia $\left(9^{\text {th }}\right.$ c. $)$ ) and then Italy (majolica, $13^{\text {th }}$ c.) and France $\left(15^{\text {th }}-16^{\text {th }}\right.$ c.) [58-61]. Attempts to imitate the Blue-and-white Chinese porcelain were first made in Anatolia with Ottoman Iznik firewares from 1450 to 1620 [62-64] and then in Italy with Medici porcelain from $~ 1575$ to 1587 [65,66], as well as in the whole of Europe one century after $\left(18^{\text {th }}\right.$ century porcelain Manufactures) [67-69]. The availability of kaolin permitted the preparation of hard-paste alumina-rich porcelain, though the soft-paste porcelain route, which could be considered as an evolution of the Iznik fritware technology. A revolution took place after 1750 with the development of faience and porcelain factories (Figure 1). A second one occurred during the $20^{\text {th }}$ century with the development of advanced ceramics, in particular dielectric passive components (capacitors, substrates, sockets, etc.) at the root of the development of microprocessors and computers [70].

Figure 1 illustrates the innovation law for the porcelain production [71]. It started in rare factories with a very specific technology. Then, attempts to produce similar artifacts were made in different places; with the circulation of persons and information, this number of places first expanded very rapidly and then decreased. Obviously, a differentiation between the first productions is easier, due to the diversity of raw materials and technologies. Indeed, competitors tried to imitate an artifact by using their specific raw materials and technology (Figure 2): therefore composition and/or microstructure 
(body) and/or nanostructure (glass, enamels, etc.) are different, though the objects look very similar. Then evolution towards the best compromise between cost and quality led to more similar objects.

Figure 1. Evolution of the number of porcelain manufactures in Europe during the $18^{\text {th }}$ century, after P. Ricciardi et al. e-preservation, 2009, 22-26. [71].

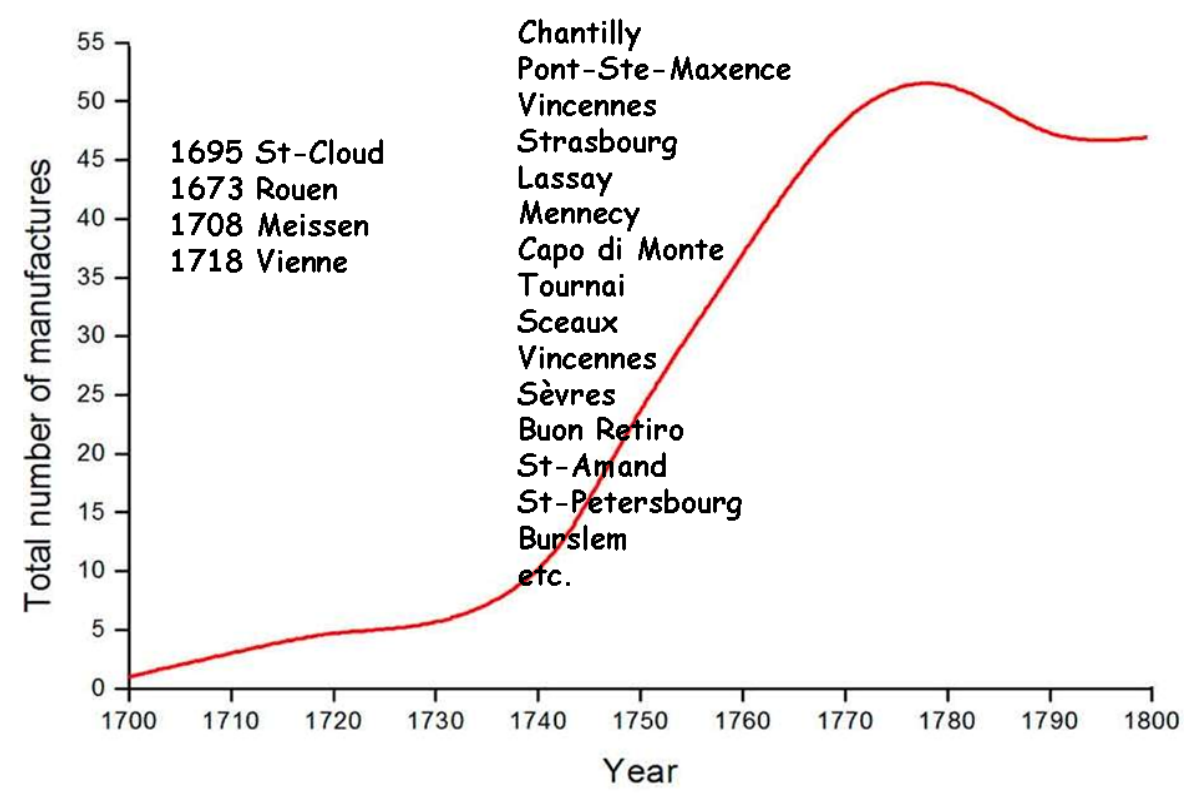

Figure 2. Evolution toward a common technology imposed by cost criteria and facilitated by the circulation of men and their know-how.

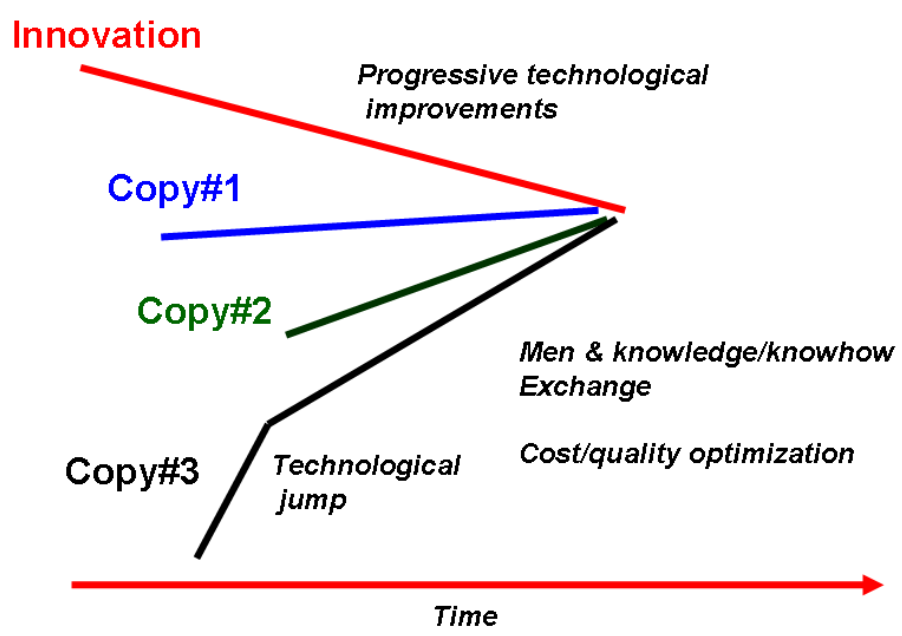

There are two difficult tasks in ceramic and glass technologies, (i) the achievement of fine, reactive powders in order to facilitate their reaction, thus melting and the wettability between liquid and solid phases to keep the glaze thickness almost constant, and (ii) the firing and its control. The first pottery clays were iron oxide-rich because a liquid phase appears at $\sim 700{ }^{\circ} \mathrm{C}$ between $\mathrm{FeO}$ and clays, promoting a good sintering in reducing atmospheres [72].

The use of microsized Mesopotamian silts allowed a perfect firing at low temperature [57]. The most difficult tasks were the glaze preparation, adhesion, and color control, which require empirical 
control at the nanoscale. However, a ceramic always shows a heterogeneous microstructure because the only goal to reach is the formation of a liquid phase at the grain interface in order to develop a soldering between grains. Only in porcelain, a large part of the body volume reaches the liquid state $(\sim 30-50 \%)$, which permits the final optical translucency [73,74]. On the other hand, the glass and glaze volume reach the liquid state leading to a 'perfect' homogeneity at the eye scale. Consequently, differences remain at a much smaller scale, the nano- and subnano-scales.

\section{The Development of Solid State Chemistry and Related Technologies Offers Chronological/Technological Milestones}

There are two methods to disperse chromophores in a glassy matrix: the first one is to dissolve $3 \mathrm{~d}$ transition metals $\left(\mathrm{Fe}^{2+}, \mathrm{Fe}^{3+}, \mathrm{Co}^{3+}, \mathrm{Mn}^{5+}, \mathrm{Cu}^{2+}\right.$, etc. $)$ or $4 \mathrm{f}$ Rare Earth ions $\left(\mathrm{Pr}^{3+}\right.$, etc.) with electronic levels absorbing in the visible range; the second one is the direct dispersion of pigment grains, a matter already containing ions of the kinds mentioned above, or more complex chromophores [75-77]. Note that the chemical and thermal stability of a pigment must be high enough not to be degraded/dissolved by the molten enamel. Each method has advantages and drawbacks. The first one is simple but hues are weak, the colors spread out easily because of the fast diffusion of small coloring ions, and reproducibility of the décor is difficult. The second technique requires sophisticated preparation (synthesis, grinding, flux addition). In both cases, the color palette is drastically reduced when the firing temperature increases.

Nature gives many examples of very vivid colors of another type, the iridescent colors that can be found for instance on blue Morphos butterflies, many beetles, opals, nacre, etc. The same kind of iridescence has been achieved by potters, centuries ago, in lustre pottery [78-80]. The color arises from scattering, i.e., positive and negative addition of the light waves (interferences) diffracted by more or less organized layers (gratings). Among modern items, the colored reflections of CD surfaces have the same physical origin.

The use of colored materials, natural or synthetic, is one of the most important foundations of Art. Some selected minerals, as well as chemical mixtures extracted from plants, wood, and animals, were used as the first raw materials [81,82].

First glazed artifacts were made of steatite, 4 millennia B.P. [83-85]. In Europe (Celts [79,83,86-88]) and Near-East (Egypt, Mesopotamia [84]) colored enamels and glasses were prepared using different chromophores, mainly metal nanoparticles, transition ions, as well as phases that form precipitates on cooling. However, since the forming elements (antimonates, stanates) [50] are major impurities of lead oxides, the main flux of glass and glaze, their precipitation was not really controlled. Consequently, improved technologies were lost repeatedly: for instance cobalt was used episodically by the Egyptians of the $18^{\text {th }}$ Dynasty ( 1500 B.C.) to color glass [89-91], and then stopped for centuries.

The mass production of pottery (Sigillata [56,92]) and glass artifacts [93] developed during Roman times. Some new technologies appeared at the end of the Roman Empire: gold tesserae in Ravenna and Byzantium [94], and the use of lapis lazuli as blue glass pigment [95], an unexpected discovery which questions the whole history of pigment technology (see further).

The Chinese chromophore technology was very specific with, for instance, the use of barium derivatives to produce violet, blue, and green colors [96-98] with a composition similar to that of 
Egyptian blue and green $[99,100]$. In actuality, great technological improvements took place during the $8^{\text {th }}$ century in China (Tang porcelains $[55,101-103]$ ) and the $9^{\text {th }}$ century in the Ancient World (Abbasids pottery $[57,104,105]$ ). The recent discovery of a Tang shipwreck cargo has changed our knowledge on the history of technological exchanges between China and the Mediterranean World [101].

Polychrome lustre pottery was produced for a few decades, only during the first Abbasids Dynasty $[78,79,104]$. A new technology, namely the yellow coloring of stained glass windows with silver metal nano-precipitates, appeared in the Middle-Ages [22,106]. Red stained glasses, a Celtic innovation [79,86-88], were prepared by alternation of very thin (tenths of micrometer) non-colored and copper metal-containing glass layers [107,108], in order to limit a too-strong light absorption. The controlled reduction of copper ions into metal nano-particles was used to make Jun, Flammés, and Sang-de-Pigeon Chinese porcelains. Cloisonnés enamels on metals, a technology that also emerged during Celtic times, continued during Byzantium, and flourished in Spain during the Middle-Ages [109]. Then, at Limoges (France), the enameling technique allowed the production of black-and-white and colored enamels on copper plates, depicting Greek, Roman, Christian, and then historical scenes $[109,110]$. The technology spread to China and then Japan [111], an example of West-to-East technology exchange. At the same time, Mamluks pushed the glass enameling to a very high level [112,113].

Painters of the Quattrocento and Renaissance used enamels and pigments developed by potters [114]. The first Technological Books became largely available [27-31] at that period.

The Ottoman Court, through the Nakashane Office, promoted the production of exquisite Fine Arts [64,65,104,115-117]. This involved a prodigious development of the ceramic pigment technology that spread out in many countries. The cross-over between the ancient praxis and beginning of the Science and Technology Epoch took place in the $18^{\text {th }}$ century with the New Chemistry and the Encyclopaedists. Many books describing preparation procedures were published [34-46]. Many manufactures were founded and routes explaining the reactions leading to specific chemicals and products, e.g., the Macquer' dictionary, became available [19]. With the turn between the $18^{\text {th }}$ and $19^{\text {th }}$ centuries, industrial workshops and the related innovations developed by mean of an increasing knowledge in solid and liquid state chemistry. Commercial colouring agents became more complexdifferent coloring agents/pigments were mixed together in a patented formula-which offered accurate chronological markers [40-45].

The onset of the development of organic chemistry took place around 1850, together with the race for the related innovating steps. People having experiences in both ceramic technology and science theory wrote books [118].

Cost and hazardous properties became very important criteria at the end of the $20^{\text {th }} \mathrm{c}$. for environmental reasons, e.g., the limitation and then the replacement of lead in glass/enamel composition. This continuous evolution gives us a variety of markers to trace production place and time.

\section{The Analytical Techniques of Artworks: Toward Non-Destructive Procedures}

To date, the history of the scientific study of ancient artifacts is poorly documented. Alexandre Brongniart (1770-1847), with his Traité des Arts Céramiques ou des poteries considérées dans leur 
Histoire, leur Pratique et leur Théorie [41], can be considered as one of the founders of this kind of approach, at least for ceramic and glass technologies. He was a follower of the Encyclopaedists and of the rare precursors such as Ehrenfried Walther von Tschirnhaus (1651-1708) [116], René-Antoine Ferchaud de Réaumur (1683-1757) [37], Pierre-Joseph Macquer (1718-1784) [19], and Georges Leclerc Comte de Buffon (1707-1788) [20]. However, his books [40,41] were the first devoted to the potters and glassmakers rather than scholars. Productions from all over the world are described and a careful attention is paid to the identification of the raw materials used and to the firing techniques. For instance, A. Brongniard noted that in Corsica, female potters produced the first ceramic matrix reinforced composites, mixing asbestos long fibres with a calcareous clay [41,117].

In the third part of the $19^{\text {th }}$ century, many technical books were rapidly published, especially in the famous Roret Encyclopédie series that covers most of the Fine Arts techniques [118]. Among books on ceramic technology and its history, 'La Faïence' from Théodore Deck (1823-1891) can be distinguished [44].

The first chemical analyses of the different parts of ancient pottery (body, glaze, lustre, etc.) was conducted by Duke of Luynes, A. Salvetat [41,42], and other famous chemists. Their studies were highly destructive.

A great improvement took place one century after ( 1950), with the development of neutron activation techniques $[119,120]$. The development of X-Ray Fluorescence (XRF) instruments in the sixties, with the bore glass bead technique (boric acid or lithium tetraborate is added as a flux to solubilise about $1 \mathrm{~g}$ of ceramic in a Pt crucible and form a glass bead permitting quantitative composition measurement) [120-123] can be considered as the true onset of archeometry literature with the help of data processing (Principal Component Analysis, Cluster variation methods, etc.) [124-127]. The increasing sensitivity and versatility of instruments (Inductively Coupled Plasma-Mass Spectroscopy (ICP-MS), Energy Dispersive Spectroscopy coupled with a Scanning Electron Microscope (EDS-SEM), etc.) significantly decreased the sampling size [90,91,128,129]. Microsampling is achieved with Laser Induced Breakdown Spectroscopy (LIBS) [130-133]. The development of accelerators with extracted particle beam gives opportunity, in rare laboratories, to study art pieces by Particle Induced X-ray Emission (PIXE), Rutherford Backscattering Spectroscopy (RBS), etc. [134-137]. Synchrotron sources offer new tools (XRF and diffraction-microbeam, Infrared microspectrometry) that have been extensively used for a few years [138-140]. However, though the brilliance of the source decreases the recording time, similar or even better results can be obtained —at a much lower cost - by using classical instruments.

Today the composition of most materials can be qualitatively determined in a micro-destructive/non-destructive way using portable XRF instruments [141-145]. In some cases (homogeneous materials, flat surfaces) the measurement can be quantitative: LIBS instruments $[145,146]$ allow profiling the composition from the surface to the bulk, by means of a few microns-sized laser beam that drills the sample.

\section{The Development of Mobile/Remote Raman Microspectroscopy}

Irradiation of matter by a coherent electromagnetic wave induces coupling with the oscillating distribution of charges; in other words, with the chemical bonds in the system. Polarization of the 
excited dipoles generates a scattered electric field and associated waves [147-149]. A small part of the incident light is scattered with an energy different from the initial one due to energy exchange with the chemical bonds, and the prediction of this effect dates back to the beginning of the $20^{\text {th }}$ century (L. Brillouin in France, A. Smekal in Russia [150,151]). First experimental evidences were given in the same month, in 1928, by different groups: two in France (Y. Roccard \& M. Ponte and J. Cabannes [152,153]), one in Berlin (P. Pringsheim \& B. Rosen [154]), one in Russia (G. Landsberg \& L. Mandelstram [154]), and one in India (K.S. Krisnan and C.V. Raman [155]). Although the latter group was not the first to publish its work, it obtained the Nobel Prize in 1930 (Raman sent many preprints all over the world and received a high impact). The effect was called 'Raman effect'. In actually, the technique relying on this phenomenon was developed in the 1970s with only the availability of $\mathrm{Ar}^{+}$and $\mathrm{Kr}^{+}$ion lasers. The development of Charge Coupled Devices and photodiode arrays in the 1980s, and then of CCD matrices in place of photomultipliers, increased the detection level by several orders of magnitude [147]. Replacement of the first monochromator stage (a diffraction grating) with Notch photonic crystals or Edge dielectric layered filters increased the detectivity significantly. Miniaturization and improvement of computers and electronic boxes allowed the size reduction of all the Raman set-up, and the conception of dedicated transportable/mobile spectrometers free of any moving parts (Figure 3). Today hand set-ups are available, but have reduced capabilities (poor resolution, low sensitivity).

Figure 3. Examples of on-site measurements with a mobile Raman set-up [144,156]; detail about the positioning of the remote optical head is given.
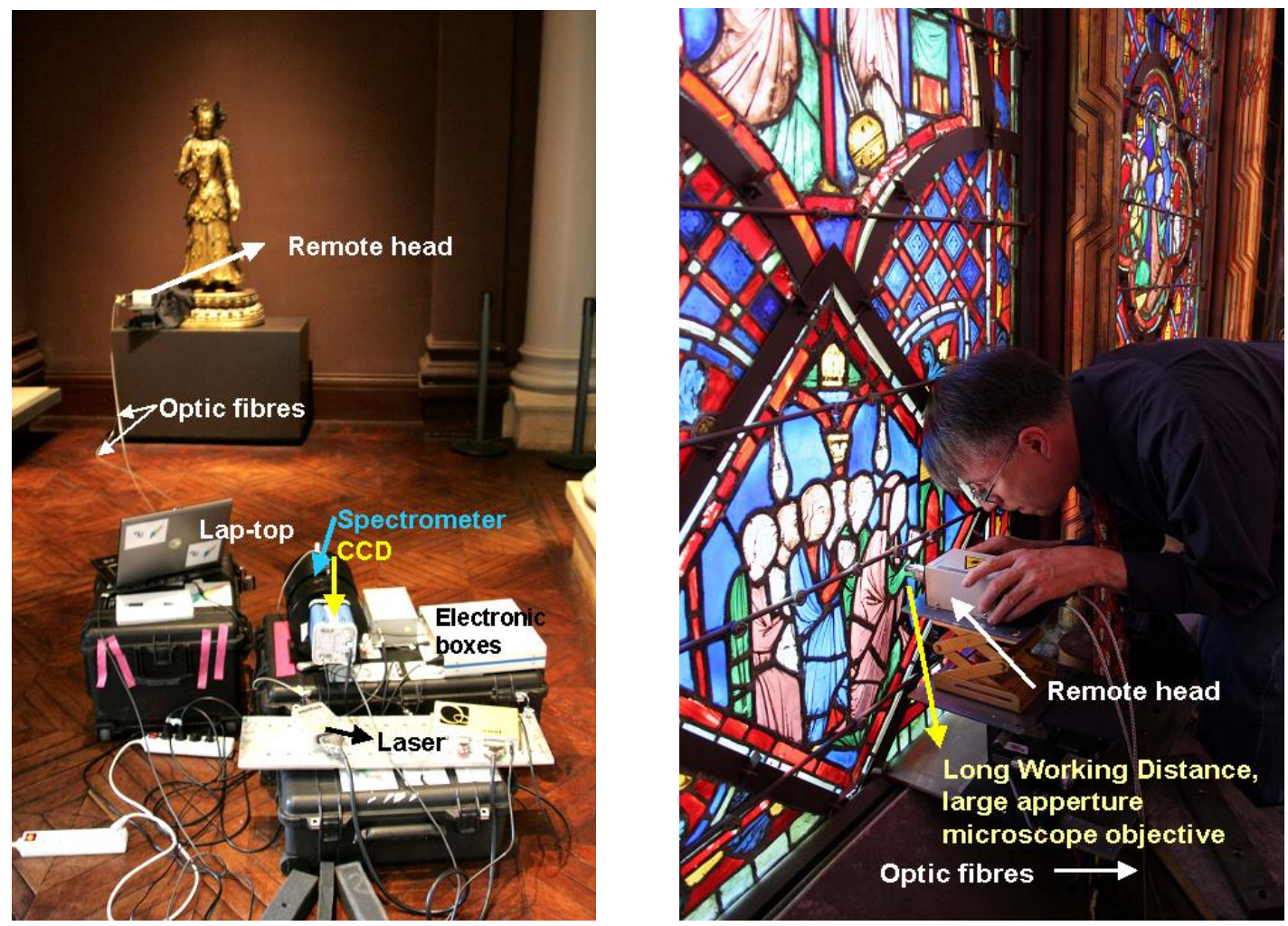

Our group is playing a pioneering role in the development of on-site Raman study of ancient (glazed) pottery [62,63,65,66], enameled glass [112,113], Limoges and Cloisonnés enamels on 
metal [109-111], paintings and drawings [157,158], patinated bronzes [144], rock art paintings [159], etc. (Figure 3). The poor resolution and complex background of spectra recorded with mobile Raman set-ups require the development of models expliciting the Raman signature and associated parameters in relation to the micro and nanostructure of matter, as well as the use of multivariate chemometric techniques [160-164] (Figures 4-6). The recent avaibility of small size laser sources with different colors is a new asset: typically, blue to green lasers are better for inorganic and light colored compounds, whereas red to infrared lasers show advantages for the study of organic and black compounds. However, red and yellow pigments are easily detected by using excitation of the red (typically 633 and $785 \mathrm{~nm}$ ) [165]. Sophisticated optics, such as objectives optimized for the laser wavelength, with a large aperture to collect the scattered light with high efficiency, and a long working distance between the focus point and the front lens (to avoid any contact with precious items), are mandatory.

Figure 4. Parameters extracted by modeling the Raman signatures of the glazes of various artifacts assigned to Iznik and Kütahya Ottoman production were classified using the cluster classification technique to establish a procedure of indentification [65,66].

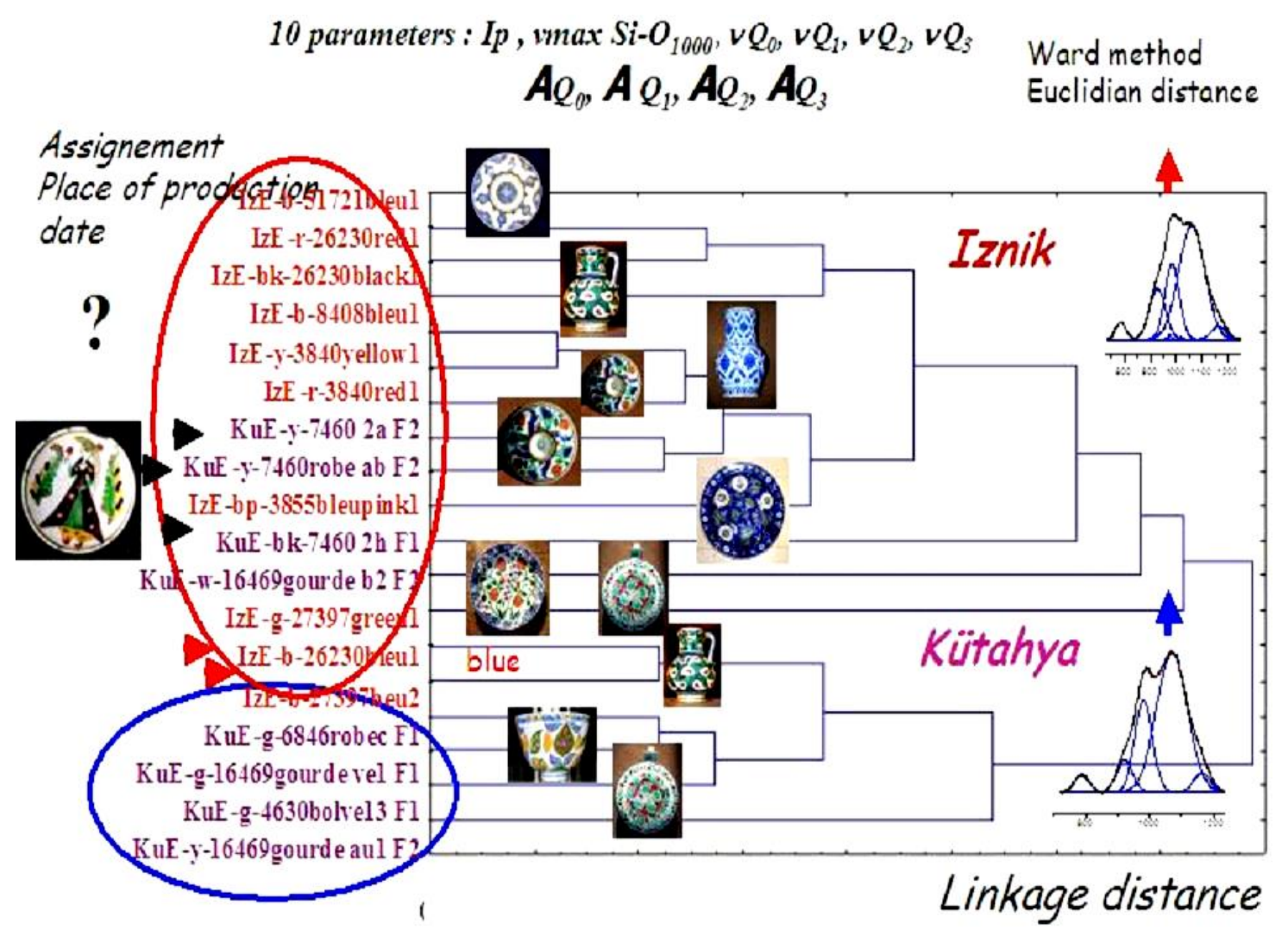

An analytical study of the Raman signal can be used to identify the phases present in the volume of the analyzed system. Typically, many non-colored minerals and compounds can be identified by simple comparaison with reference spectra found in databases [75,165-172]. The narrower bandwidth of many signatures leads to a better detectivity of minor phases by Raman spectroscopy than by IR spectroscopy. However, the large variation of the Raman signal intensity with chemical bond polarizabilities (no spectrum for ionic bonding compounds, intense spectrum for covalent bonding compounds) renders quantitative analysis difficult. 
Figure 5. (a) The limited scattering of the $\mathrm{Q}_{n}$ stretching components of $\mathrm{SiO}_{4}$ tetrahedra indifferent Roman glass artifacts excavated in France, Italy, and Tunisia results from the controlled mass production using a single composition; on the other hand, the dispersed data measured for stained glass windows from Northern and Eastern France medieval churches arise from production by many different workshops [163]; (b) the absolute intensity of the Raman signal decreases with time because of the surface degradation of glass artifacts (leaching and microcracking); (c) the example given for Sainte-Chapelle (Paris) Rose window shows the easy differentiation by comparing as-recorded peak intensity between middle-aged and $19^{\text {th }}$ century restored pieces [156]: \#5, 1 and 2-type glass pieces are restored pieces; \#4-type pieces are original weathered stained glass pieces ; (d) examples of Raman spectra as-recorded on enameled artifact with a mobile Raman setup: the signature of pigments (two Naples yellow glaze) and colored glaze (cobalt blue glaze) is recorded with a rather good intensity, when the signature of non-colored glass consists of tiny broad peaks on the complex background due to the Edge filter.

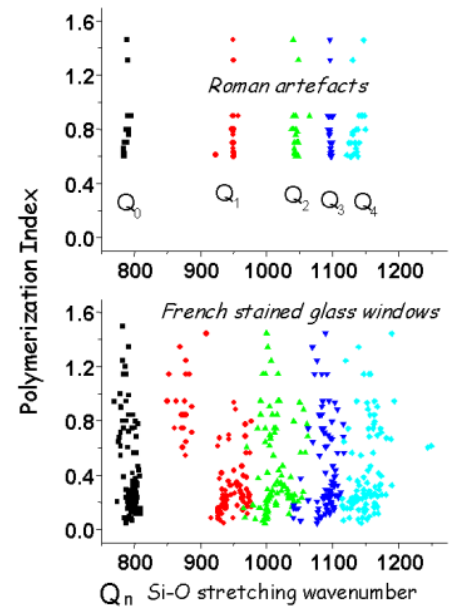

(a)

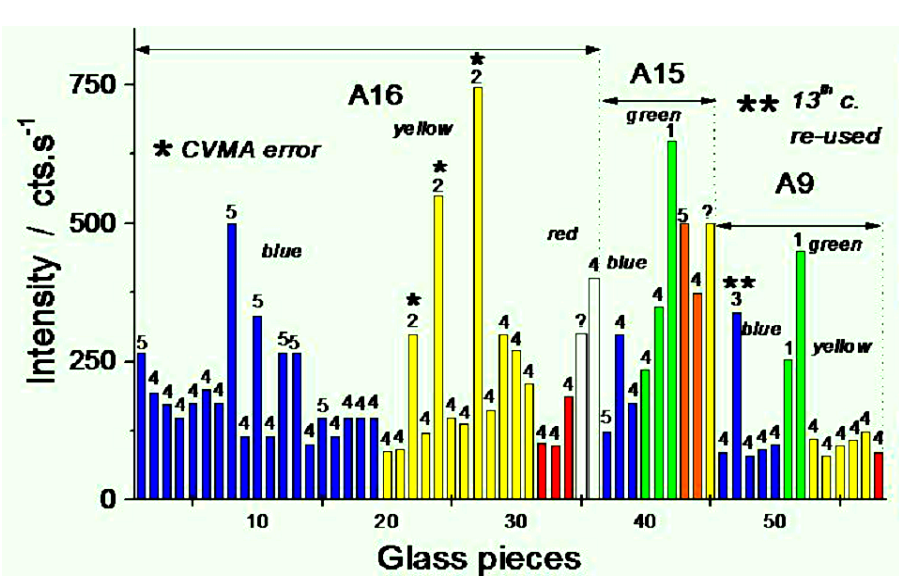

(c)

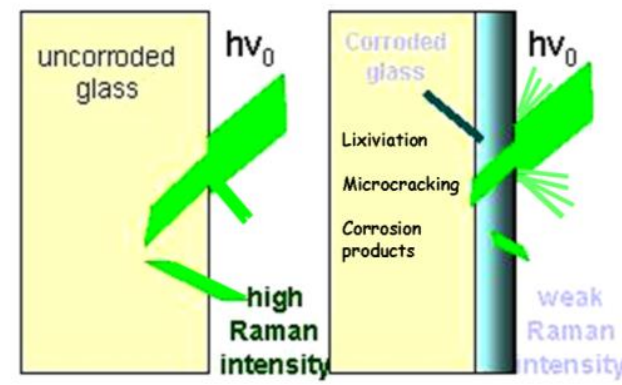

(b)

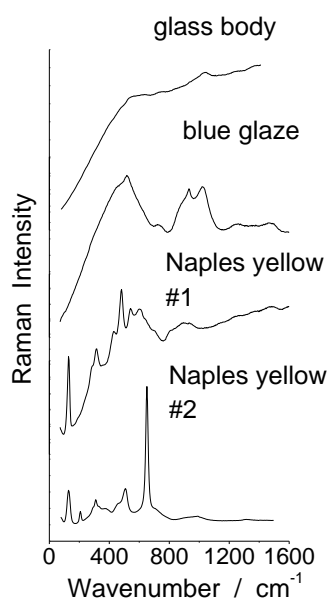

(d)

Recently available (portable) IR spectrometers give very useful information in the case of samples with flat, glossy surfaces [173,174]. 
The specific interaction between the laser light and the electronic levels of chromophores [117, 173175] gives rise to Raman resonance that leads to a high detectability, but requires a deep understanding of the phenomenon and, therefore, prevents from using databases. Instead, a Solid State PhysicoChemist approach is mandatory [176-179]. This approach, through the modeling of the Raman signal, allows for the analysis of the micro and nanostructure of matter, thus detecting many technological signatures in the objects: second phases, short range-order and structural distorsions, grain orientation and shape,

etc. A discussion of the different models developed, especially for poor crystalline materials (Figure 6), is out of the range of this text but can be found in refs [160-164].

Figure 6. Diagram built with the highest wavenumber of bending and stretching bands in silicate glass signatures; each couple is characteristic of a given composition/nanostructure. Examples of typical compositions are given (stars). See references for details $[108,109,111-113,160-164,179,180]$.

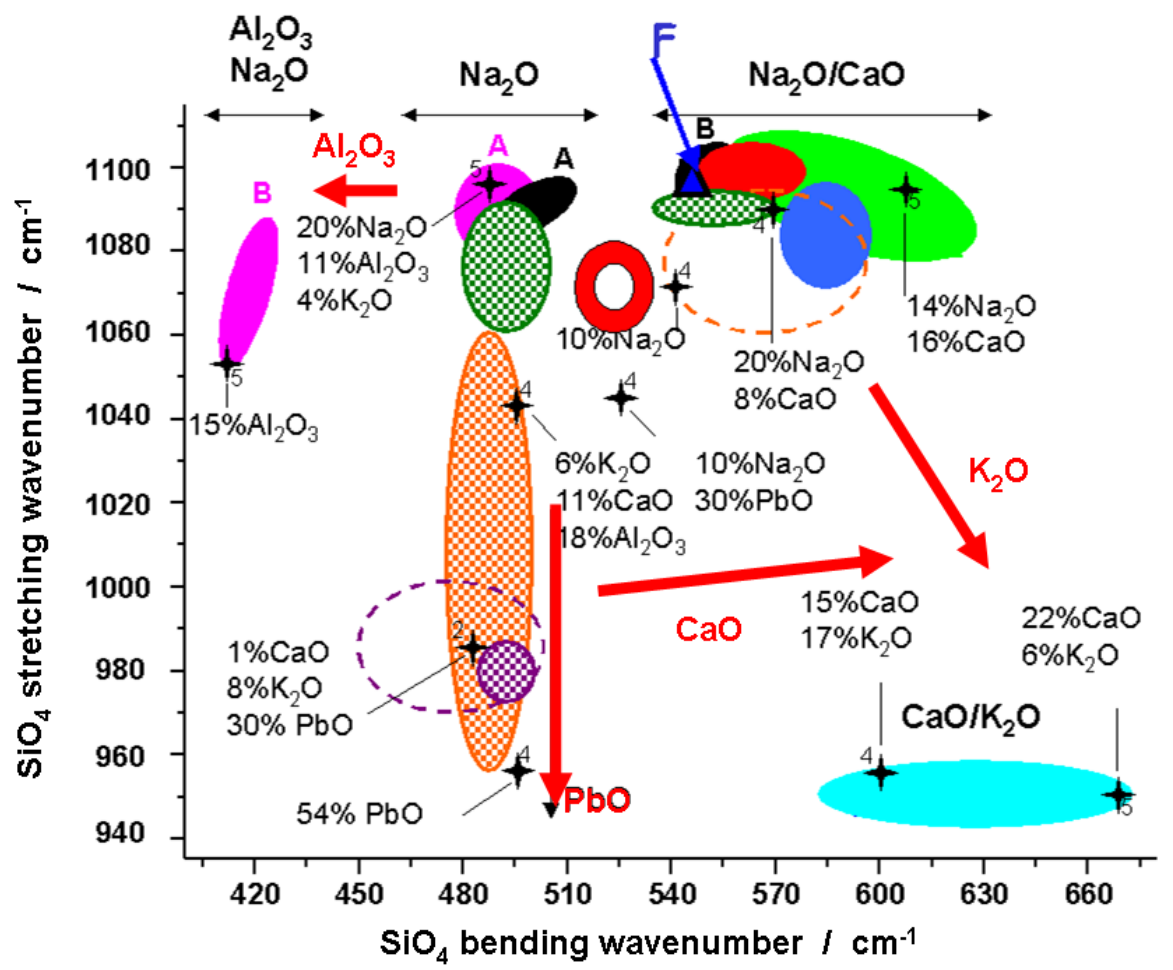

\section{Case Studies: White, Blue, Yellow, Green, Red, and Black Pigments and Coloring Agents}

In order to illustrate the interest of chronological/technical markers we shall consider the different techniques used to achieve colors in glass and pottery.

\subsection{White}

The white color of a glass is obtained by dispersing a second phase within the glassy matrix; the dispersed phase must have a higher optical index than the matrix, to give a very efficient opacification. The particle/heterogeneity size must be smaller than the eye resolution, a few $\mu \mathrm{m}$ or less, typically. The opacification of a glaze masks the body coloration in order to depict a decor. Glaze, like any 
enameling, must have a thermal expansion slightly higher than the body to avoid cracking or scaling [174].

The simplest way to opacificy a glass (Table 1) is by dispersion of micronic bubbles (e.g., in Celadon [177,178] and first Meissen porcelains [179]). Other ways are the dispersion of micrometric grains of quartz [62], the precipitation of antimoniates [58-61,180], wollastonite [66,67], cassiterite [57,58,67,105], fluorite [111], calcium phosphates (bone opacification) [65,112,113], arsenates [109], as well as the addition of rutile, anatase and zircon in modern productions [76]. White slips and deposits, fired or not, are also used to obtain a white décor on terra cotta. Many of these phases are post quem markers. Many of the above compounds were also used in paintings, frescoes, illuminating manuscripts, etc. e.g., in refs [81,180-185].

Table 1. White pigments and opacifiers. Dates of innovation (first production) are given.

\begin{tabular}{|c|c|c|}
\hline Color & Composition & Date \\
\hline Bone white & $\mathrm{Ca}_{2}\left(\mathrm{PO}_{4}\right)_{2}$ & Antiquity \\
\hline Chalk (calcite) & $\mathrm{CaCO}_{3}$ & Antiquity \\
\hline Cerussite & $\mathrm{PbCO}_{3}$ & Antiquity \\
\hline Gypsum & $\mathrm{CaSO}_{4} 2 \mathrm{H}_{2} \mathrm{O}$ & Antiquity \\
\hline Bassanite & $\mathrm{CaSO}_{4} 1 / 2 \mathrm{H}_{2} \mathrm{O}$ & $?$ \\
\hline Anhydrite & $\mathrm{CaSO}_{4}$ & Antiquity \\
\hline Antimoniate & $\mathrm{CaSb}_{2} \mathrm{O}_{7}, \mathrm{CaSb}_{2} \mathrm{O}_{6}$ & Antiquity \\
\hline Kaolin & $\mathrm{Al}_{2} \mathrm{O}_{3}, 2 \mathrm{SiO}_{2}, 2 \mathrm{H}_{2} \mathrm{O}$ & Antiquity \\
\hline Lead white ceruse & $\mathrm{Pb}(\mathrm{OH})_{2}$ & $500 \mathrm{BC}$ \\
\hline Cassiterite & $\mathrm{SnO}_{2}$ & 9 th \\
\hline Fluorite & $\mathrm{CaF}_{2}$ & 14 th? \\
\hline Quartz & $\mathrm{SiO}_{2}$ & 16th. \\
\hline Arsenates & $(\mathrm{Ca}, \mathrm{Pb})_{1.5} \mathrm{AsO}_{4}$ & 17 th \\
\hline Zinc white & $\mathrm{ZnO}$ & 1781 (1834) \\
\hline Lithopone & $\mathrm{ZnS}-\mathrm{BaSO}_{4}$ & 1874 (Western) \\
\hline \multirow[t]{2}{*}{ Titanium white } & $\mathrm{TiO}_{2}$ anatase & 1916 (1923) \\
\hline & $\mathrm{TiO}_{2}$ rutile & 19 th? \\
\hline Freeman' white & $\mathrm{PbSO}_{4}$ & 19th \\
\hline Hamburg white & $\mathrm{PbCO}_{3}, \mathrm{BaSO}_{4}$ & 19 th \\
\hline Barium white & $\mathrm{BaSO}_{4}$ & 19th (Western) \\
\hline Zirconia & $\mathrm{ZrO}_{2}$ & 20 th \\
\hline Zircon & $\mathrm{ZrSiO}_{4}$ & 20th \\
\hline
\end{tabular}

\subsection{Blue}

Egyptian blue, a more or less crystalline copper-lime silicate (Table 2), can be considered the first synthetic pigment [99]. Besides, the earlier white (or yellow) antimoniate pigments may result from natural precipitation, once saturation is achieved during the cooling of the melt. Millennia later, Chinese Han potters developed a Baryum homolog to Egyptian blue [97,98] for the decoration of the famous terra cotta army of the Qui Shi Huang Xiang mausoleum.

The turquoise blue color was first obtained in Egypt by firing silicawares (synthetic or natural stone) in a copper-rich paste leading to a turquoise blue glazing of the object surface $[41,84]$. 
Episodically (18 ${ }^{\text {th }}$ Dynasty), cobalt was used instead $[88,89]$. These techniques use the dissolution of $3 \mathrm{~d} \mathrm{Cu}^{2+}$ or $\mathrm{Co}^{2+}$ ions in the glassy silicate.

Table 2. Name and composition of blue pigments and coloring agents. Dates of innovation (first production) are given.

\begin{tabular}{|c|c|c|c|}
\hline Color & Hue & Composition & Date \\
\hline Egyptian blue & Light blue & $\mathrm{CaCuSi}_{4} \mathrm{O}_{10}$ & $3000 \mathrm{BC}$ \\
\hline Turquoise & & $\mathrm{Cu}^{2+}$ in alkaline glass & $2000 \mathrm{BC}$ \\
\hline Han blue & & $\mathrm{BaCuSi}_{4} \mathrm{O}_{10}$ & $200-500 \mathrm{BC}$ \\
\hline Han violet & & $\mathrm{BaCuSi}_{2} \mathrm{O}_{6}$ & $200 \mathrm{BC}$ \\
\hline Smalt & Light blue & $\mathrm{CoO} \mathrm{nSiO}_{2} ; \mathrm{Co}$-containing glass & Antiquity \\
\hline Lapis Lazuli (Lazurite) & ultramarine & $\mathrm{Na}_{8}\left[\mathrm{Al}_{6} \mathrm{Si}_{6} \mathrm{O}_{24}\right] \mathrm{S}_{\mathrm{n}}$ & Roman \\
\hline Cobalt,-manganese-iron ores & & dissolved & 9th \\
\hline Indigo & & $\mathrm{C}_{16} \mathrm{H}_{10} \mathrm{~N}_{2} \mathrm{O}_{2}$ indigotin & $<10$ th? \\
\hline Prussian blue & & $\mathrm{Fe}_{4}\left[\mathrm{Fe}(\mathrm{CN})_{6}\right]_{3} 14-16 \mathrm{H}_{2} \mathrm{O}$ & 1704 \\
\hline Cobalt blue & Dark blue & $\mathrm{CoSiO}_{2}$ olivine & 18th \\
\hline Cobalt blue & Dark blue & $\mathrm{CoAl}_{2} \mathrm{O}_{4}$ spinel & $1775(1802)$ \\
\hline Cerulean & Dark blue & $\mathrm{Co}_{2} \mathrm{SnO}_{4}$ spinel & $1810(1821)$ \\
\hline Cobalt chromite & & $\mathrm{Co}(\mathrm{Al}, \mathrm{Cr})_{2} \mathrm{O}_{4}$ spinel & \\
\hline Synthetic ultramarine & & & 1826 \\
\hline Cobalt spinel & & $\begin{array}{l}(\mathrm{Co}, \mathrm{Zn}) \mathrm{Al}_{2} \mathrm{O}_{4} \text { spinel } \\
\mathrm{CoAl}_{2} \mathrm{O}_{4} / \mathrm{Co}_{2} \mathrm{SnO}_{4} \text { spinel }\end{array}$ & 19th \\
\hline Spinel aluminate blue & $\begin{array}{l}\text { Blue } \\
\text { Turquoise blue } \\
\text { Dark blue } \\
\text { Violet } \\
\text { Blue grey } \\
\text { Dark blue green } \\
\text { Light blue green } \\
\end{array}$ & $\begin{array}{l}\mathrm{Al}_{2} \mathrm{O}_{3} ; 0,5 \mathrm{ZnO} ; 0,5 \mathrm{CoO} \\
\mathrm{Al}_{2} \mathrm{O}_{3} ; 0,2-0,4 \mathrm{CoO} ; 0,6-0,8 \mathrm{ZnO} \\
\mathrm{Al}_{2} \mathrm{O}_{3}, 2\left(\mathrm{PO}_{4}\right)_{2} \mathrm{Co}_{3} \text { ou } 2\left(\mathrm{AsO}_{4}\right)_{3} \mathrm{Co}_{3} \\
\mathrm{Al}_{2} \mathrm{O}_{3} ; 0,5 \mathrm{CoO} ; 0,5-1 \mathrm{MgO} \\
\mathrm{Al}_{2} \mathrm{O}_{3} ; 0,6-0,8 \mathrm{CoO} ; 0,4-1,2 \mathrm{NiO} \\
\mathrm{Al}_{2} \mathrm{O}_{3} ; \mathrm{CoO} ; \mathrm{Cr}_{2} \mathrm{O}_{3} \\
\mathrm{Al}_{2} \mathrm{O}_{3} ; \mathrm{CrO}_{4} ; \mathrm{CoO} ; \mathrm{ZnO}\end{array}$ & $\sim 1900$ \\
\hline Zircon blue & $\begin{array}{l}\text { Light blue } \\
\text { Turquoise } \\
\text { Light blue }\end{array}$ & $\begin{array}{l}\mathrm{ZrO}_{2}, \mathrm{SiO}_{2}+\mathrm{V}_{2} \mathrm{O}_{5}(<1 \%) \\
+\mathrm{NaCl} \text { or } \mathrm{NaF} \\
+\mathrm{Na}_{2} \mathrm{CO}_{3}\end{array}$ & $\sim 1950$ \\
\hline Cobalt oxide & Dark blue & $\mathrm{Co}_{3} \mathrm{O}_{4}$ & \\
\hline Zincochromite & Dark blue & $\mathrm{ZnCr}_{2} \mathrm{O}_{4}$ & \\
\hline Cobalt zinc oxide & Light blue & $\mathrm{ZnCo}_{2} \mathrm{O}_{4}$ & \\
\hline Posnjakite & & $\mathrm{CuSO}_{4} 3 \mathrm{Cu}(\mathrm{OH})_{2} \mathrm{H}_{2} \mathrm{O}$ & \\
\hline Cyprium & & $\mathrm{Na}_{3} \mathrm{Ca}\left(\mathrm{Al}_{3} \mathrm{Si}_{3} \mathrm{O}_{12}\right)$ & \\
\hline Vivianite & & $\mathrm{Fe}_{3}\left(\mathrm{PO}_{4}\right)_{2} 8 \mathrm{H}_{2} \mathrm{O}$ & \\
\hline Phtalocyanine blue & & $\mathrm{C}_{32} \mathrm{H}_{16} \mathrm{CuN}_{8}$ & 20th \\
\hline Manganese blue & & $\mathrm{BaMnO}_{4}$ & 20th \\
\hline
\end{tabular}

The preparative chemistry of cobalt (chromium, etc.) is difficult: a small addition of cobalt $(0.5-2 \mathrm{wt} \%)$ is sufficient to color a silicate glass, while higher cobalt-levels generally lead to precipitation of cobalt silicate (lead-rich glass) [67,75] or cobalt-aluminate (alumina-rich glaze) $[186,187]$. Consequently, before the $19^{\text {th }}$ century, cobalt sources were natural ores containing very 
large amount of other transition metals such as manganese, iron, or chromium [90,91,177,188]. For instance Chinese/Vietnamese cobalt sources were manganese- and iron-rich ores, and the porcelain firing was performed under strongly reducing atmosphere so that the dark color of $\mathrm{Mn}^{4 / 5+}$ and $\mathrm{Fe}^{3+}$ ions would not obscure the blue hue [188 and references herein]. Since cobalt ores remain rare, recycling of blue glass was reported in remote antiquity.

The main alternative to obtain a nice blue color is the use of lapis lazuli, a stone associating lazurite or hauÿne feldspars (colored by some $\mathrm{S}_{2}{ }^{-}$ions located in site of the feldspar structure) with pyrite and diposide. Sources of lapis lazuli, are scarce: mainly in Afghanistan, and for a minor part in Baikal Lake mines and in Chile [189-192]. Moreover, the access to Afghanistan mountains mines was difficult, and stopped in different periods of history, especially during Sassanid Dynasties. Consequently, many scholars in Western Countries considered lapis lazuli as a very rare material and therefore rejected its use in glass and ceramic. Raman studies have shown that this view was erroneous. The first evidence for the use of lapis lazuli as a glaze pigment was given by Clark et al. on pottery excavated in a $14^{\text {th }} \mathrm{c}$. Swabian-Normand-Islamic context [193-195]. If cobalt was easily detected by analytical techniques such as ICP or XRF [91,92,192,196,197], the detection of lapis lazuli small grains, dispersed in a silicate matrix by the same methodology, was not possible: first, because the composition of the feldspar host framework is close to that of the glass, and second, because the $\mathrm{S}$ traces are masked by $\mathrm{SO}_{4}$ traces, common in ancient glasses. On the contrary, the Raman resonance of the $\mathrm{S}_{2}{ }^{-}$chromophore under green laser excitation allowed detecting the presence of S-doped feldspar very easily $[95,113,157,180,193]$. Thus, it was demonstrated that both cobalt and lapis lazuli could be used simultaneously in the glaze of a rather common Lâjvardina artifact, contradicting the alleged high cost of these pigments at the period considered $\left(14^{\text {th }}\right.$ c.) [190]. It is now obvious that during the $14^{\text {th }}-15^{\text {th }}$ centuries, lapis lazuli was a common blue pigment. A recent study also points out that a Roman enameled glass, the Lübsow beaker, already contained lapis lazuli as blue pigment [95]. Mamluk enameled glass objects as well as the blue enamel of the famous Begram Treasure [198] were also made using this blue pigment [113]. In addition, the discovery of glass shards in Frederick II Melfi's castle, dated from the second half of the $13^{\text {th }}$-first half of $14^{\text {th }}$ century, gives arguments in support to a direct link between Roman-Byzantine glassmakers/potters and Islamic ones through the SwabianNormand Court [193-195].

An unexpected use of Lapis lazuli was observed in the first hard-paste Meissen porcelains made by J.F. Böttger [179]: the selected kaolin has iron oxide traces and the fired body remains gray, not white. The opacification of the glaze was only achieved by dispersion of micronic bubbles, a technique not sufficient to completely cover the gray color of the body. To achieve a white color, Böttger, educated as lapidarian expert, added lapis lazuli blue grains at the body-glaze interface: the artifact looked as white as the Chinese model, made with Kaolin of higher quality. Different modern ceramic pigments are now available to obtain blue color [76,77,165,187,199].

\subsection{Yellow}

Stable yellow colors are difficult to prepare. The easiest way to obtain a yellow glaze is to saturate a silicate with lead, inducing precipitation of massicot $\mathrm{PbO}$ [58]. With the development of majolica wares, Naples yellow, a large pyrochlore solid solution between $\mathrm{PbO}-\mathrm{SnO}_{2}-\mathrm{Sb}_{2} \mathrm{O}_{3} / \mathrm{Sb}_{2} \mathrm{O}_{5}$ with addition 
of $\mathrm{SiO}_{2}, \mathrm{Fe}_{2} \mathrm{O}_{3}$, and $\mathrm{ZnO}$ became the most widely used pigment [59-61]. Because of the very large range of the solid solution, the composition actually achieved is specific to a factory and, therefore, a good production marker [112,200].

Table 3. Name and composition of yellow pigments and coloring agents. Dates of innovation (first production) are given.

\begin{tabular}{|c|c|c|}
\hline Color & Composition & Date \\
\hline Ochre & $\mathrm{FeO}(\mathrm{OH})$ goethite & Neolithic \\
\hline Massicot & $\mathrm{PbO}$ & Antiquity \\
\hline Orpiment \& pararealgar & $\mathrm{As}_{2} \mathrm{~S}_{3}-\mathrm{As}_{4} \mathrm{~S}_{4}$ & Antiquity? \\
\hline Saffron & $\mathrm{C}_{20} \mathrm{H}_{24} \mathrm{O}_{4}$ crocetin & Antiquity \\
\hline Ocre & $\mathrm{Fe}_{2} \mathrm{O}_{3} \mathrm{H}_{2} \mathrm{O}+$ clays $+\mathrm{SiO}_{2}$ & Neolithic \\
\hline $\begin{array}{l}\text { Naples yellow } \\
\text { Lead-antimony yellow }\end{array}$ & $\mathrm{Pb}_{2} \mathrm{Sb}_{2} \mathrm{O}_{7}$ pyrochlore & $1500 \mathrm{BC}$ \\
\hline Palmatine & {$\left[\mathrm{C}_{21} \mathrm{H}_{18} \mathrm{NO}_{4}\right]^{+} \mathrm{X}^{-}$} & Antiquity \\
\hline $\begin{array}{l}\text { Naples yellow } \\
\text { Lead-tin yellow type I }\end{array}$ & $\mathrm{Pb}_{2} \mathrm{SnO}_{4}$ & Antiquity \\
\hline Berberine & {$\left[\mathrm{C}_{20} \mathrm{H}_{18} \mathrm{NO}_{4}\right]^{+}$} & Antiquity \\
\hline Silver yellow & Ag nanoparticules in glass matrix & 12th \\
\hline Or mussif & $\mathrm{SnS}_{2}$ & 13th. \\
\hline Indian yellow & $\mathrm{MgC}_{19} \mathrm{H}_{16} \mathrm{O}_{11} 5 \mathrm{H}_{2} \mathrm{O}$ & 15th. \\
\hline $\begin{array}{l}\text { Naples yellow } \\
\text { Lead-tin yellow type II }\end{array}$ & $\mathrm{PbSn}_{x} \mathrm{Si}_{\mathrm{x}} \mathrm{O}_{3}$ & 15 th? \\
\hline Strontium yellow & $\mathrm{SrCrO}_{4}$ & 1800 \\
\hline Barium yellow & $\mathrm{BaCrO}_{4}$ & 19th. \\
\hline Cadmium yellow & $\mathrm{CdS}(+\mathrm{CdSe})$ & $1829(1845)$ \\
\hline Chrome yellow/orange & $\mathrm{PbCrO}_{4}(+\mathrm{PbO})$ & $1809(1820)$ \\
\hline Aureolin & $\mathrm{K}_{3}\left[\mathrm{CO}\left(\mathrm{NO}_{2}\right)_{6}\right] \mathrm{nH}_{2} \mathrm{O}$ & 1861 \\
\hline Cambodia yellow & $\mathrm{C}_{38} \mathrm{H}_{44} \mathrm{O}_{8}$ et $\mathrm{C}_{29} \mathrm{H}_{36} \mathrm{O}_{6}$ & \\
\hline Rutile yellow & $(\mathrm{Ti}, \mathrm{Ni}, \mathrm{Nb}) \mathrm{O}_{2}$ rutile & 20th \\
\hline Cassiterite yellow & $(\mathrm{Sn}, \mathrm{V}) \mathrm{O}_{2}$ cassiterite & 20th \\
\hline Primrose yellow & $2 \mathrm{Ni}, 3 \mathrm{BaO}, 17 \mathrm{TiO}_{2}$ priderite & 20th \\
\hline Zinc yellow & $\mathrm{ZnCrO}_{4}$ & $1809(1850)$ \\
\hline Curcuma & $\mathrm{C}_{21} \mathrm{H}_{20} \mathrm{O}_{6}$ & \\
\hline Uranium yellow & $\mathrm{PbUO}_{4}$ & 19th \\
\hline Stibine & $\mathrm{Sb}_{2} \mathrm{O}_{5}$ & \\
\hline Malayite yellow & $\mathrm{CaSnSiO}_{5}$ sphene malayite & 20th \\
\hline Praseodymium yellow & & 20th \\
\hline
\end{tabular}

New pigments were searched for during the $19^{\text {th }}$ and $20^{\text {th }}$ centuries (Table 3 ) to obtain a variety of yellow hues, such as uranium yellow, zinc-chrome yellow, rutile yellow, Praseodymium yellow, etc. [76,77,165,199].

A specific mention must be made of silver yellow: yellow glasses are prepared by diffusion of $\mathrm{Ag}^{+}$ silver ion from the glass surface inward and then in situ reduction into metal nanoparticles to obtain coloration by the $\mathrm{Ag}^{\circ}$ plasmon light absorption. This technique was first described in middle-age 
reports $[22,79,106]$. Because the plasmon absorption is very strong, the layer colored by silver metal particles must be very thin to keep its transparency (see further the discussion for red copper glass).

Note that the huge plasmon absorption peak makes the observation of low wavenumber nanoparticle modes difficult under excitation with absorbed laser wavelength [79]. In this case, the Raman spectrum only reflects the nanostructure around the metal nanoparticle and does not correspond to the glass matrix $[57,79,106,108,201]$.

\subsection{Green}

Green glasses and glazes have been obtained since the Egyptian times: Egyptian potters and glassmakers prepared a greenish derivative of Egyptian blue (different composition, different crystallinity) by diffusion of copper ions into a silica-rich body — or stone - from a Cu-rich paste in which the artifact was wrapped $[41,84,85,165,199]$.

Roman craftsmen prepared copper-containing lead-based glass. This technique remained the only one for a while, inducing in China [101-103], before the use of chromium-rich ores by Iznik Ottoman potters developed [62,63]. However, other minerals were used as pigments for paintings and illuminating manuscripts (Table 4): malachite, green earths, vert-de-gris, etc. [81,165,183-185,199].

Table 4. Name and composition of green pigments and coloring agents. Dates of innovation (first production) are given.

\begin{tabular}{|c|c|c|}
\hline Color & Composition & Date \\
\hline Malachite & $\mathrm{CuCO}_{3} \mathrm{Cu}(\mathrm{OH})_{2}$ & Antiquity \\
\hline Atacamite & $\mathrm{CuCl}_{2} 3 \mathrm{Cu}(\mathrm{OH})_{2}$ & Antiquity \\
\hline Green earth & $\mathrm{K}\left[\left(\mathrm{Al}^{3+}, \mathrm{Fe}^{3+}\right)\left(\mathrm{Fe}^{2+}, \mathrm{Mg}^{2+}\right)\right],\left(\mathrm{AlSi}_{3}, \mathrm{Si}_{4}\right) \mathrm{O}_{10}(\mathrm{OH})_{2}$ & Antiquity \\
\hline \multirow[t]{3}{*}{ Vert-de-gris } & $\mathrm{Cu}\left(\mathrm{CH}_{3} \mathrm{COO}\right)_{2}$ & \multirow[t]{3}{*}{ Middle age } \\
\hline & {$\left[\mathrm{Cu}\left(\mathrm{CH}_{3} \mathrm{COO}\right)_{2}\right]_{2} \mathrm{Cu}(\mathrm{OH})_{2} 5 \mathrm{H}_{2} \mathrm{O}$} & \\
\hline & $\mathrm{Cu}\left(\mathrm{CH}_{3} \mathrm{COO}\right)_{2} \mathrm{Cu}(\mathrm{OH})_{2}$ & \\
\hline Green & $\mathrm{Cr}$ in glass & Ottoman \\
\hline Scheele green & $\mathrm{Cu}\left(\mathrm{AsO}_{2}\right)_{2}$ & 1778 \\
\hline Cobalt green & $\mathrm{CoO} \mathrm{nZnO}$ & $1780,>1830$ \\
\hline Dark green & $\mathrm{Cr}_{2} \mathrm{O}_{3}$ haematite & 1800 \\
\hline Emerald green & $\mathrm{Cu}\left[\mathrm{C}_{2} \mathrm{H}_{3} \mathrm{O}_{2}\right] 3 \mathrm{Cu}\left[\mathrm{AsO}_{2}\right]_{2}$ & 1814 \\
\hline Viridian & $\mathrm{Cr}_{2} \mathrm{O}_{3} 2 \mathrm{H}_{2} \mathrm{O}$ & $1838(1859)$ \\
\hline \multirow[t]{4}{*}{ Victoria green } & $3 \mathrm{CaO}, \mathrm{Cr}_{2} \mathrm{O}_{3}, 3 \mathrm{SiO}_{2}$ & \multirow[t]{9}{*}{ 19th } \\
\hline & Yellow green: $+\mathrm{CaCl}_{2} \& \mathrm{CaF}_{2}$ & \\
\hline & Dark green: $+\mathrm{CaF}_{2}$ & \\
\hline & Middle green: $+\mathrm{LiF}$ & \\
\hline Chromium & Light green: $\mathrm{ZrO}_{2}, \mathrm{SiO}_{2}, \mathrm{Na}_{2} \mathrm{WO}_{4}, \mathrm{~K}_{2} \mathrm{Cr}_{2} \mathrm{O}_{7}, \mathrm{NaCl}$ & \\
\hline Green & Olive: $\mathrm{ZrO}_{2}, \mathrm{SiO}_{2}, \mathrm{Na}_{2} \mathrm{WO}_{4}, \mathrm{NaCl}$ & \\
\hline Nickel green & $\mathrm{Ni}_{2} \mathrm{SiO}_{4}$ olivine & \\
\hline Chromite green & $\mathrm{CoCr}_{2} \mathrm{O}_{4}$ spinel & \\
\hline Cobalt green & $\mathrm{Co}_{2} \mathrm{TiO}_{4}$ spinel & \\
\hline Yellow + blue & Yellow pigments in blue matrix & 18th \\
\hline
\end{tabular}


Green color is also achieved by dispersing yellow pigments in a blue matrix [75]. Chromium-based pigments were developed during the $18^{\text {th }}$ century and still compete with organic chromophores for many applications.

\subsection{Red}

The technique to obtain red glass using a dispersion of copper nanoparticles can be considered, with the pottery technology itself, as the first example of nanotechnology $[79,80,106]$. Indeed, the possibility to prepare, at relatively low temperature, a variety of ceramic is directly related to the nanosized character of clay particles, which allows their dispersion in water as colloid or gel. The control of the rheology, plasticity, and high reactivity of the latter phases then permits the low firing temperature [202]. The controlled dispersion of a small quantity of copper (red), silver (yellow to brown) and gold (red) metal nanoparticles in an optically clear glass gives rise to colorful materials through the specific interaction of light with the electron gas at the particle surface, the so-called plasmon resonance (Figure 7). This leads to narrow peak absorption and more complex features related to the particle composition, size, and shape $[57,79,106,201]$.

Table 5. Name and composition of red pigments and coloring agents. Dates of innovation (first production) are given.

\begin{tabular}{|c|c|c|}
\hline Color & Composition & Date \\
\hline Copper red & Co metal nanoparticles in glass matrix & Neolithic \\
\hline Vermillion & $\mathrm{HgS}$ & Neolithic \\
\hline Ochre \& Earths & $\mathrm{Fe}_{2} \mathrm{O}_{3}+$ clay $+\mathrm{SiO}_{2}$ & Neolithic \\
\hline Haematite & $\alpha-\mathrm{Fe}_{2} \mathrm{O}_{3}$ & Neolithic \\
\hline Purpurin & $\mathrm{C}_{4}{ }_{4} \mathrm{H}_{18} \mathrm{O}_{5}$ & $3000 \mathrm{BC}$ \\
\hline Tyr purple & $\mathrm{Cl}_{6} \mathrm{H}_{10} \mathrm{Br}_{2} \mathrm{~N}_{2} \mathrm{O}_{2}$ & $1400 \mathrm{BC}$ \\
\hline Litharge & $\mathrm{PbO}$ & Antiquity \\
\hline Minium & $\mathrm{Pb}_{3} \mathrm{O}_{4}$ & Antiquity \\
\hline Kermes & $\mathrm{C}_{6}{ }_{6} \mathrm{H}_{10} \mathrm{O}_{8}$ & Antiquity \\
\hline Realgar & $\mathrm{As}_{4} \mathrm{~S}_{4}$ & Antiquity \\
\hline Haematite/hercynite & $\mathrm{Fe}_{2} \mathrm{O}_{3}+\mathrm{SiO}_{2}$ & Antiquity \\
\hline Umbria earth & $\mathrm{Fe}_{2} \mathrm{O}_{3}, \mathrm{MnO}_{2}+$ clay $+\mathrm{SiO}_{2}$ & \\
\hline $\begin{array}{l}\text { Cassius' purple } \\
\text { Kinkel' red }\end{array}$ & Au metal nanoparticles in glass matrix & Roman? \\
\hline Madder & $\mathrm{C}_{14} \mathrm{H}_{8} \mathrm{O}_{4}$ & Middle-age \\
\hline Carmine & $\mathrm{C}_{14} \mathrm{H}_{8} \mathrm{O}_{4}$ (alizarin) + purpurin & 16th. \\
\hline Armenian Bole & $\mathrm{Fe}_{2} \mathrm{O}_{3}+$ clay $+\mathrm{SiO}_{2}$ & 14 th \\
\hline Thiviers sandstone & $\mathrm{Fe}_{2} \mathrm{O}_{3}+\mathrm{SiO}_{2}$ & 17 th \\
\hline Mars red & $\mathrm{Fe}_{2} \mathrm{O}_{3}$ synthetic, nanosized & $<18$ th. \\
\hline Mendipite & $\mathrm{Pb}_{3} \mathrm{O}_{2} \mathrm{Cl}_{2}$ & \\
\hline Cadmium red & $\mathrm{CdS}(+\mathrm{CdSe})$ & 1907 \\
\hline
\end{tabular}

Copper dispersion in glass was controlled by Celts, millennia ago [79,86-88], and red Roman mosaic tesserae were prepared with the same technique [180,203]. Silver dispersion was largely used to prepare yellow middle-age stained glass windows $[26,106,118]$, and gold ruby glasses made by 
Renaissance glass-makers are famous [108,116,118,196,197,204,205]. Rare artifacts such as the Licurgus cup $\left(4^{\text {th }}\right.$ century) $[79,206,207]$ or some Roman tesserae contain both copper/silver and gold [203], indicating that ruby gold glasses date back at least to the end of the Roman Empire.

Figure 7. (a) UV-visible absorbance curve of a $19^{\text {th }}$ century typical glass, free from or with a $200 \mu \mathrm{m}$ thick $\mathrm{Cu}^{\circ}$-containing layer exhibiting a plasmon peak; (b) optical micrograph of a Middle-Age red flashed glass showing alternate colored and non-colored glass. This example shows the sophistication of the ancient technology (after [108]).

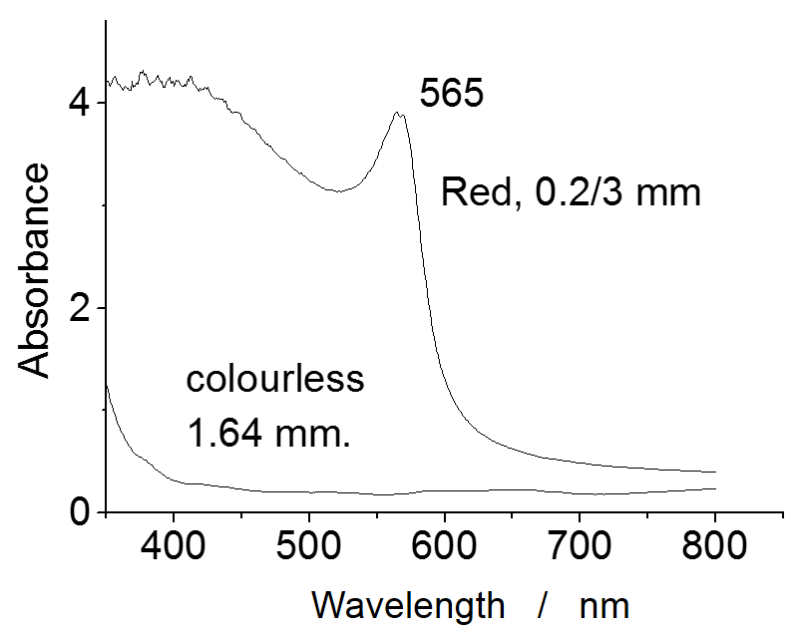

(a)

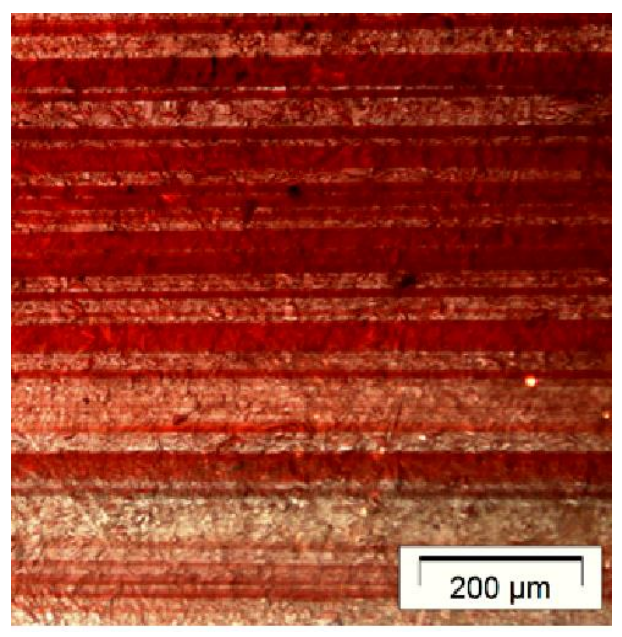

(b)

Another way to obtain a nice red or orange color is the use of nanosized haematite or parent structures. The size reduction of particles, by broadening the electronic absorption bands, decreases the electronic gap, leading to a small change of color. This phenomenon is at the origin of the nice color of Roman Sigillatta [56], where the orange to red color of the fired slip arises from the association of micronic haematite and corundum grains. Rather similar fine microstructures are observed for Iznik red (Armenian bole) [64,65], red Meissen décor, and French faience red décor obtained using Thiviers sandstone as red pigment precursor [208]. Note that fake red dots made with organic pigments can be observed on ancient Islamic masterpieces, "embellished" in order to improve their commercial value [112].

\subsection{Black}

Although the black color is easily obtained from carbon by controlled firing of organic precursors (plants, bones, ivory, etc.) [157,158,165,199], the preparation of a black glaze/enamel in association with other colors is very difficult, especially in oxidizing firing atmospheres [209] and dates from the Ottoman period in Western Countries (Table 6). Song potters produced outstanding black glazed artifacts that continue to attract the interest of modern potters [210]. On the other hand, black terra cotta décors had been obtained since the beginning of pottery, and achieved a very high level in the Greek period by controlled reduction of iron-rich clays and slips [211,212].

Note the early use of Bismuth [205]. New ceramic pigments were developed during the $19^{\text {th }}$ century. 
Table 6. Name and composition of black pigments and colouring agents. Dates of innovation (first production) are given.

\begin{tabular}{ccc}
\hline Color & Composition & Date \\
\hline Carbon black & $\mathrm{C}$ & Neolithic \\
Earths & $\mathrm{MnO}_{2}$, clays, $\mathrm{Fe}(\mathrm{OH})_{3}$ & Neolithic \\
Bismuth black & $\mathrm{Bi}$ & $>15$ th \\
Spinel black & $\mathrm{Cr}_{2} \mathrm{MnO}_{4}$ spinel & 15 th \\
Tin-massicot & $\mathrm{Pb}_{2} \mathrm{SnO}_{4}$ & \\
Copper black & $\mathrm{CuO}$ & \\
Cobalt black & $\mathrm{CoO}$ & \\
\hline
\end{tabular}

\section{Lustre, Another Way to Master the Color}

Rare ancient reports suggest that iridescent glass has been prepared in (late) Roman times [118], but to date no actual artifacts has been described and a fortiori studied. Some scholars say that the first lustres were made on glass artifacts a few decades before Abbasids lustre pottery (Mesopotamia, $9^{\text {th }}$ century) [104]. However, examination of the objects - in their more or less preserved state - points out that their lustre level is very limited. Further studies are necessary to clarify the lustre origin.

Lustre coloration is obtained by combination of plasmon absorption and interferences [78,79]. An interference-built color requires a very specific orientation of the observer's eyes $v s$. the artifact and the source of light (Figure 8), as well as a very specific micro/nanostructure of the material, made of a transparent matrix with an 'organized' dispersion of silver, copper, or gold nanoparticles.

Figure 8. (a) The Transmission Electronic Microscopy micrograph of a modern lustre replica prepared by combined oxidizing- $\mathrm{CO}$ reducing sequences shows the metal nanoparticle-rich layers in the silicate matrix (Courtesy of Ph. Sciau, CEMES, Toulouse); (b) the copper nanoparticle-containing lustre glaze exhibits the well-defined Plasmon peak in the yellow-green range, the color of the plasmon peak depending on the nanoparticles shape and size. For most of the observation angles, this Fatimid's lustre (Fustât excavation, Egypt) looks reddish but for a specific orientation $v s$. the enamel surface, the viewer and the light source, the diffraction takes place, giving a golden shining. Metal nanoparticle-containing glasses, called dichroic glasses, have different color in reflexion and transmission.

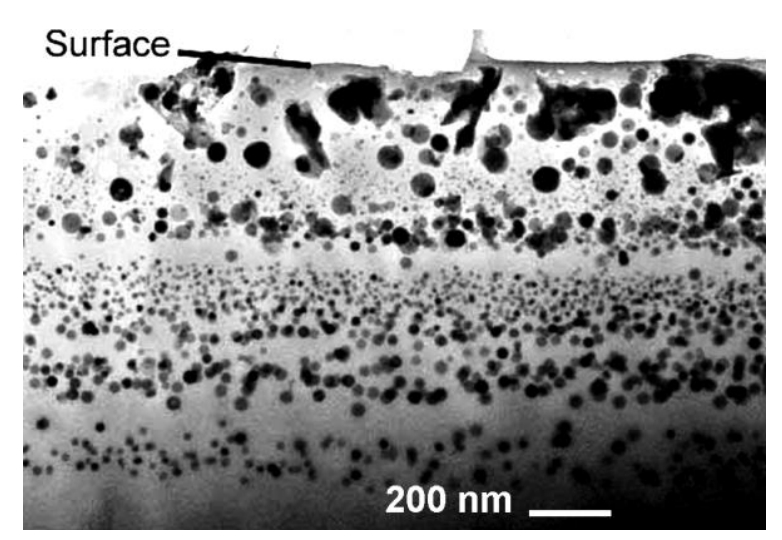

(a)

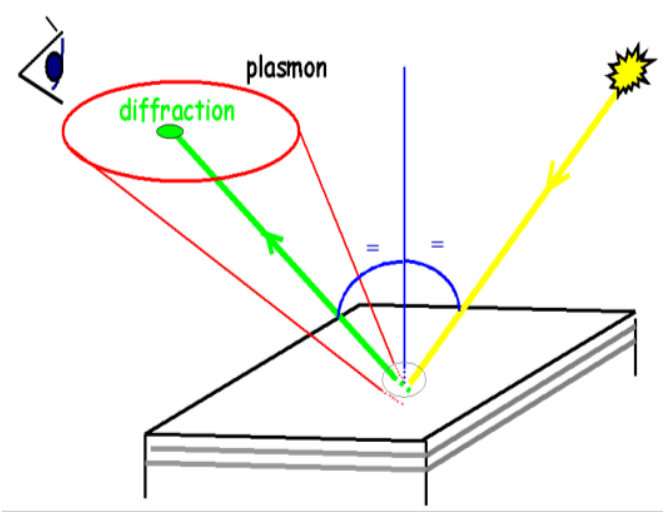

(b) 
Figure 8a shows the near surface section of the Fatimid lustre shard. Metal particles appear in dark. So the upper region appears free from metal particles and the alternation of layers with and without metal particles is obvious. The precise chemical analysis of the dark particles shows that they consist of small silver and copper, rarely alloyed, single crystals $[79,80]$. Copper can exist both as $\mathrm{Cu}^{\circ}$ metal particles and as dissolved $\mathrm{Cu}^{+}$or $\mathrm{Cu}^{2+}$ ions. The upper oxidized particle-free layer plays an important role for the optical properties. Namely, this impedance adaptation layer promotes penetration of light down to the metal-containing layers, maximizing the scattering and hence the single color lustre shining in combination with the number of layers, with and without metal nanoparticles. Large disorder in the particle shape and size distribution destroys the interference contribution, letting the color be determined by the plasmon absorption: red for copper, golden brown for silver. Abbasid and Fatimid Lustres show well-defined interferences and lustre shining [78-80].

Rare polychrome Lustre pottery shards have been excavated from Susa and Samara. The best example is the tile series forming the décor of Kairuan mosque (Tunisia, [78]): for a given observation angle, blue and green lustres are observed on a tile simultaneously. Such high-quality polychrome lustres seem to have been produced only during a few decades. Majolica and Mudejar lustres do not exhibit various colors [78-80], and are very similar to more modern lustres like Meissen, Burgos, or Lüdersdorff productions, or even bismuth-based metallization [118].

\section{Conclusion: Master's Secrets as Chronological/Technological Milestones}

The use of mobile, non-destructive Raman spectroscopy, notwithstanding the important instrumental limits $v$ s. fixed instruments excited with a variety of laser wavelength, has allowed the achievement of important results. It outlines the technologies, with the essential advantage of preserving the objects in their museum rooms. The development of new mobile Raman instruments able to perform mapping (as under development for Mars explorations) and/or excited with blue or UV laser should improve the efficiency of the mobile Raman technique for the study of these and other artifacts.

Raman analysis of several examples of enameled glass objects and glazed pottery/porcelain yielded important information both on the coloring agents/pigments used and on the technological procedures employed. As an illustration, Table 7 lists remarkable case studies, pointing out specific use of Lapis lazuli and/or unexpected white opacifiers identified by Raman scattering. Identification of these unexpected pigments offers criteria to follow the transmission of a technology as well as to differentiate genuine, embellished/restored, or fake artifacts.

Table 7. Technologies used to obtain blue and white hues as evidenced by Raman microscopy.

\begin{tabular}{lllc}
\hline Artifact & Period & Technology & Ref. \\
\hline Begram glass Treasure & $1^{\text {st }}$ century AD & Lapis lazuli & {$[198]$} \\
& Roman Empire & & {$[213]$} \\
\hline Ptolemaic faience pottery & $1^{\text {st }}$ century AD & Lapis lazuli & \\
& Roman Empire & & {$[95]$} \\
\hline Lübsov glass beaker & $2^{\text {nd }}$ century AD & Lapis lazuli as blue \& calcium & \\
& Roman Empire & antimonate as white pigments & \\
\hline
\end{tabular}


Table 7. Cont.

\begin{tabular}{|c|c|c|c|}
\hline Artifact & Period & Technology & Ref. \\
\hline Abbasid pottery & $9^{\text {th }} c$. & Cassiterite opacifier; Lustre & {$[57]$} \\
\hline Lâjvadina pottery, Iran & $13^{\text {th }} \mathrm{c}$. & $\begin{array}{l}\text { Lapis lazuli and cobalt as blue glaze } \\
\text { pigments }\end{array}$ & {$[189,190]$} \\
\hline $\begin{array}{l}\text { Enameled glass and Pottery, Frederic } \\
\text { II Souabian Court, Apuglia }\end{array}$ & $13^{\text {th }}-14^{\text {th }} \mathrm{c}$. & $\begin{array}{l}\text { Lapis lazuli as blue \& calcium } \\
\text { phosphate as white pigments }\end{array}$ & {$[195]$} \\
\hline Mamluk mosque lamps & $13^{\text {th }}-14^{\text {th }} \mathrm{c}$ & $\begin{array}{l}\text { Lapis lazuli as blue } \& \text { calcium } \\
\text { phosphate as white glaze pigments }\end{array}$ & {$[113,198]$} \\
\hline $\begin{array}{l}\text { Medici porcelain } \\
\text { Florence }\end{array}$ & $1575-1587$ & $\begin{array}{l}\text { Calcium phosphate } \\
\text { Feldspar \& wollastonite }\end{array}$ & {$[65]$} \\
\hline $\begin{array}{l}\text { Böttger porcelain } \\
\text { Meissen }\end{array}$ & $1700-1708$ & $\begin{array}{l}\text { Lapis lazuli grains at the body-glaze } \\
\text { interface. Bubble as opacifier. }\end{array}$ & {$[179]$} \\
\hline
\end{tabular}

\section{References and Notes}

1. Rickard, T.A. L'Homme et les Métaux; Editions Gallimard: Paris, France, 1938.

2. Forbes, R.J. Metallurgy. In A History of Technology; Singer, C.H., Holmyard, E.J., Hall, A.R., Williams, T.J., Eds.; Oxford University Press: Oxford, UK, 1975; Volume 1.

3. Gilles, B. Histoire des Techniques; Encyclopédie de la Pléiade, Editions Gallimard: Paris, France, 1978.

4. Rosmoduc, J. Une histoire de la Physique et de la Chimie; Editions du Seuil -Points-Sciences: Paris, France, 1985.

5. Bensaude-Vincent, B.; Stengers, I. Histoire de la Chimie; La Découverte: Paris, France, 1992.

6. Djebbar, A. Une histoire de la Science arabe - Entretiens avec J. Rosmorduc, Editions du Seuil Points-Sciences: Paris, France, 2001.

7. Rashed, R. Histoire des Sciences Arabes; Technologie, alchimie et sciences; Editions du Seuil: Paris, France, 1997; Volume 3.

8. Lory, P. Jàbir ibn Hayyàan, Dix traités d'alchimie. Les dix premiers traités du livre des Soixantes-dix (Textes traduits et présentés); Sindbad: Paris, France, 1983.

9. Gimpel, J. La révolution industrielle du Moyen Age; Editions du Seuil - Points-Histoire: Paris, France, 1975.

10. Cosandey, D. Le Secret de l'Occident - Vers une Théorie Générale du Progrès Scientifique; Champs-Flammarion: Paris, France, 2007.

11. Herodote, Historia ( 450 BC, Athènes); translated and edited by Larcher and Charpentier: Paris, France, 1850.

12. Theophraste. Recherches sur les Plantes-Le Livre des Pierres (Athènes, 300 B.C.); Les Belles Lettres: Paris, France, 2006;tome V.

13. Dioscoride, P. De Materia Medica (Rome, 60); Henri Estienne: Paris, France, 1516.

14. Pline. Naturalis Historia; Vol XII-XXXVII (Rome, 77); French translation, Veuve Desaint: Paris, France, 1771.

15. Strabon. Geôgraphiká (Rome, 20); Hamilton, H.C., Transl.; Falconer, W., Bohn, H.G., : London, UK, 1854-1857. 
16. Gougguenheim, S. Aristote au Mont Saint-Michel - Les Racines Grecques de l'Europe Chrétienne; Editions du Seuil - L’Univers Historique: Paris, France, 2008.

17. Lambert, A. Bibliothèque de Physique et d'Histoire Naturelle; Veuve David Jeune, Paris, France, 1758; Volume 5.

18. (Abbé) Nollet, J.A. Leçons de Physique Expérimentale; Les Frères Guerin: Paris, France, 1769; Volume 6.

19. Macquer, M. Elemens de Chymie-Pratique; Herissant, J.-T., Ed.; 1751, Paris. Dictionnaire de Chymie, Didot, Paris, France, 1766-1777; Volume 2.

20. Buffon (Georges Leclerc Comte de); Histoire Naturelle des Minéraux; Imprimerie Royale: Paris, France, 1787; Volume 7.

21. Théophilus $\left(11^{\text {th }}-12^{\text {th }}\right.$ c. $)$; Schedula Diversarum Artium; Dodwell, C.R., Transl.; Theophilus: the various arts, London, UK, 1961.

22. Anonymous. El Lapidario del Rey Alphonso X; translation in Spanish by King Alfonso in the year 1279, see ibidem in N. Heaton, J. British Society of Master Glass-Painters 1947, 48, 9-24.

23. Lautier, Cl.; Sandron, D. Antoine de Pise - L'art du vitrail vers 1400; Comité des travaux historiques et scientifiques (CTHS, Coll. Corpus Vitrearum - France, série «Études »: , Paris, France, 2008; vol. VIII.

24. al-Qâsem Kâshâni Abu; Arâyes al-javâher; Afshâr, I., Ed.; Teheran, 1966; see also ibidem J.W. Allan Iran, 1973, 11, 111-140.

25. Porter, Y. Les Techniques du lustre Métallique - Jowhar-Nâme-ye-Nezâm (1196), Actes du VIIe Congrès International sur la Céramique Médiévale en Méditerranée, Thessaloniki, 11-16 October 1999, Caisse des Recettes Archéologiques: 2003, Athènes, Grece, pp427-436.

26. Cannela, A.-F. Gemmes, verre coloré, fausses pierres précieuses au Moyen Âge, Le quatrième livre du «Trésorier de Philosophie naturelle des pierres précieuses » de Jean d'Outremeuse, Bibliothèque de la Faculté de Philosophie et Lettres de l'Université de Liège-Fascicule CCLXXXVIII, Librairie Droz S.A.: Genève, Suisse, 2006.

27. Picolpasso, C. Li Tre Libri dell'Arte del Vasaio, 1557, first translated and edited by C. Popelin, Les trois Livres de l'Art du Potier, (Paris, 1881). See also The Three Book of the Potter's Art, La Revue de La Céramique et du Verre (Fac-Similé Edition), Vendin-le-Vieil, France 2007.

28. Bauer, G. alias Agricola; De Re Metallica; Froben: Basel, 1556 (Fac-similé Edition), Klopp, G., Transl.; Klopp Editeur-Imprimeur; Thionville, 1987.

29. Perez de Vargas, B. De Re Metallica; Madrid, Spain, 1568. idem Traité Singulier de Métallique, Prault Père: Paris, France, 1743.

30. Rosetti, G. Plictho de l'arte de Tentori(1548), Edelstein, S.M., Borghetty, H.C., Transl.; The MIT Press: Cambridge, MA, USA, 1969.

31. Lomazzo, G.P. Trattato Dell'arte Della Pittura; Paolo Gottardo Ponto; Milan, Italy, 1590.

32. Merrett, C. The World's Most Famous Book on Glassmaking 'The Art of Glass' by Antonio Neri, Cable, M., Ed.; Sheffield, England, 1662, see, The Society of Glass and Technology Reprint, $2003\left(1^{\text {rst }}\right.$ published in 1612).

33. Brunet, P. Les premiers linéaments de la Science Géologique: Agricola, Palissy, G. Owen, Rev. Hist. Sci. Appl. 1950, 3, 67-79. 
34. Alléon-Dulac, J.-L. Mémoire pour servir à l'histoire naturelle des provinces de Lyonnais, Forez et Beaujolais, imprimé chez Claude Cizeron, Lyon, France, 1765.

35. Merrifield, M.P. Medieval and Renaissance Treatises on the Arts of Painting (1849); reprint, Merified; New York, NY, USA, 1967.

36. Berthelot, M. Introduction à la Chimie des Anciens; Steinheil: Paris, France, 1889.

37. Ferchault de Réaumur, R.A. Observations sur la matière qui colore des perles fausses et sur quelques autres matières animales d'une semblable couleur, à l'occasion de quoi on essaie d'expliquer la formation des écailles de poissons, Mémoires Académie des Sciences, Paris, France, 1716. Idée générale des différentes manières dont on peut faire la Porcelaine et quelles sont les véritables matières de celle de la Chine, ibidem, 1727. Second mémoire sur la porcelaine ou suite des principes qui doivent conduire dans la composition des porcelaines de différents genres et qui établissent les caractères des matières fondantes qu'on ne peut choisir pour tenir lieu de celle qu'on employe à la Chine, ibidem, 1729. Mémoire sur l'art de faire une nouvelle espèce de Porcelaine par des moyens extrêmement simples et faciles ou de transformer le verre en porcelaine, ibidem, 1739.

38. Lewis, W. Glass and Enamel by Preparations of Gold. In Commercium Philosophico-Technicum; or, The Philosophical Commerce of Arts: Designed as an Attempt to Improve Arts, Trades, and Manufactures; London, UK, 1763; p. 170.

39. d'Albis, A. Steps in the Manufacture of the Soft Paste Porcelain of Vincennes, According to the Book of Hellot. In Ancient Technology to Modern Science; Kingery, W.D., Ed.; Ceramic and Civilization Serie: The American Ceramic SocIety; Columbus, USA, 1984; Volume 1.

40. Brongniart, A. Mémoire sur la Peinture sur Verre; Imprimerie Sellingue: Paris, France, 1829; see also Mezzadri, B.; Revue de la Céramique et du Verre, 1986, 26, 5-10.

41. Brongniart, A. Traité des Arts Céramiques ou des Poteries Considérées dans leur Histoire, leur Pratique et leur Théorie, 3rd ed.; with Notes et Additions by Salvetat, A., Asselin, P., Libraire de la Faculté de Médecine: Paris, France, 1877; Volume 2.

42. Salvetat, L.A. Leçons de Céramiques professées à l'Ecole Centrale des Arts et Manufactures; Malet-Bachelier: Paris, France, 1857.

43. Bontemps, G. Guide du Verrier-Traité Historique et Pratique de la Fabrication des Verres, Cristaux, Vitraux; Librairie du Dictionnaire des Arts Manufacturés: Paris, France, 1868.

44. Deck, Th.; La Faïenc; Maison Quantin: Paris, France, 1887.

45. Bastenaire-Daudenart, F. L'Art de fabriquer la faïence; La Librairie Scientifique et Industrielle, De Mahler et Cie, Paris, France, 1827.

46. Jacquemart, A. Histoire de la Céramique; Librairie Hachette et Cie: Paris, France, 1875.

47. Cooper, E. Ten Thousand Years of Pottery; British Museum Press: London, UK, 2000.

48. Vandiver, P.B.; Soffer, O.; Klina, B.; Svoboda, J. The origin of ceramic technology at Dolni-Vestonice Czechoslovakia. Science 1989, 246, 1002-1008.

49. Begouen (Comte de); La Grotte préhistorique, C.R. Séances Acad. Inscription Belles Lett. 1912, 56, 532-538.

50. McCray, P. Prehistory and History of Glassmaking Technology; The American Ceramic Society: Westerville, OH, USA, 1998; Ceramics and Civilization Series Volume VIII. 
51. Kingery, W.D. Ancient Technology to Modern Science; The American Ceramic Society: Westerville, OH, USA, 1984; Ceramic and Civilization Volume I.

52. Kingery, W.D. Technology and Style; The American Ceramic Society: Westerville, OH, USA, 1986; Ceramic and Civilization Volume II.

53. Kingery, W.D. High Technology Ceramics -Past, Present, and Future. The Nature of Innovation and Change in Ceramic Technology; The American Ceramic Society: Westerville, OH, USA, 1986; Ceramic and Civilization Volume III.

54. McGovern, P.E.; Notis, M.D.; Kingery, W.D. Cross-craft and Cross-Cultural Interactions in Ceramics; The American Ceramic Society: Westerville, OH, USA, 1989; Ceramic and Civilization Volume IV.

55. Li, J. The Evolution of Chinese Pottery and Porcelain Technology. In Ancient Technology to Modern Science; Kingery, W.D., Ed.; The American Ceramic Society: Westerville, OH, USA, 1984; Ceramic and Civilization Volume I, pp. 135-162,

56. Leon, Y.; Lofrumento, C.; Zoppi, A.; Carles, R.; Castelluci, E.M.; Sciau, P. Micro-Raman investigation of terra sigillata slip: A comparison study of central Italian and southern Gaul productions. J. Raman Spectrosc. 2010, 41, 1550-1555.

57. Colomban, P.; Truong, C. A Non-destructive Raman Study of the Glazing Technique in Lustre Potteries and Faiences $\left(9^{\text {th }}-14^{\text {th }}\right.$ centuries): Silver ions, Nanoclusters, Microstructure and Processing. J. Raman Spectrosc. 2004, 35, 195-207.

58. Colomban, P.; Sagon, G.; Louhichi, A.; Binous, H.; Ayed, N.; Identification par Microscopie Raman des Tessons et Pigments de Glaçures de l'Ifryqiya (Dougga: XI-XVIIIe siècles). Revue d'Archéomètrie 2001, 25, 101-112.

59. Rosi, F.; Manuali, V.; Grygar, T.; Bezdicka, P.; Brunetti, B.G.; Sgamellotti, A.; Burgio, L.; Seccaroni, C.; Miliani, C. Raman scattering features of lead pyroantimonate compounds: Implication for the non-invasive identification of yellow pigments on ancient ceramics. Part II. In situ characterisation of Renaissance plates by portable micro-Raman and XRF studies. J. Raman Spectrosc. 2011, 42, 407-414.

60. Sandalinas, C.; Ruiz-Moreno, S.; López-Gil, A.; Miralles, J. Experimental confirmation by Raman spectroscopy of a $\mathrm{Pb}-\mathrm{Sn}$-Sb triple oxide yellow pigment in sixteenth-century Italian pottery. J. Raman Spectrosc. 2006, 37, 1146-1153.

61. Sakellariou, K.; Miliani, C.; Morresi, A.; Ombelli, M. Spectroscopic investigation of yellow majolica glaze. J. Raman Spectrosc. 2004, 35, 61-67.

62. Colomban, P.; Milande, V.; Le Bihan, L. On-site Raman Analysis of Iznik pottery glazes and pigments. J. Raman Spectrosc. 2004, 35, 527-535.

63. Colomban, P.; de Laveaucoupet, R.; Milande, V. On Site Raman Analysis of Kütahya fritwares. J. Raman Spectrosc. 2005, 36, 857-863.

64. Simsek, G.; Geckinli, E. An assessment study of tiles from Topkap1 Palace Museum with energy-dispersive X-ray and Raman spectrometers. J. Raman Spectrosc. 2012, 43, 917-927.

65. Colomban, P.; Milande, V.; Lucas, H. On-site Raman analysis of medici porcelain. J. Raman Spectrosc. 2004, 35, 68-72. 
66. Colomban, P. Recent case studies in the raman analysis of ancient ceramics: Glaze opacification in abbasid pottery, medici and $18^{\text {th }}$ century french porcelains, iznik and kütahya ottoman fritwares and unexpected lapis lazuli pigment in lajvardina wares. MRS Fall Meet. Proc. 2005, 852, 153-160.

67. Colomban, P.; Robert, I.; Roche, C.; Sagon, G.; Milande, V. Identification des porcelaines tendres du $18^{\text {ème }}$ siècle par spectroscopie Raman: Saint-Cloud, Chantilly, Mennecy et Vincennes/Sèvres. Revue d'Archéomètrie 2004, 27, 153-167.

68. Colomban, P.; Treppoz, F. Identification and differentiation of ancient and modern european porcelains by raman macro- and microspectroscopy. J. Raman Spectrosc. 2001, 32, 93-102.

69. Comte, X. de Chavagnac, Marquis de Grollier. In Histoire des Manufactures Françaises de Porcelaine; A. Picard \& Fils: Paris, France, 1906.

70. Mostaghaci, H. Advanced Ceramic Materials; Trans Tech Publications, Zuerich-Uetikon, Switzerland, 1996; Key Engineering Materials Volume 122-124.

71. Ricciardi, P.; Colomban, P.; Fabbri, B.; Milande, V. Towards the establishment of a Raman database of early European porcelain. e-Preserv. Sci. 2009, 6, 22-26.

72. Phase Diagrams for Ceramists; American Ceramic Society: Westerville, OH, USA, 1971; Volume 10.

73. Carty, W.M.; Senapati, U. Porcelain-raw materials. J. Am. Ceram. Soc. 1998, 81, 3-20.

74. Carter, C.B.; Norton, M.G. Ceramic Materials-Science and Engineering; Springer: New York, NY, USA, 2007.

75. Colomban, P.; Sagon, G.; Faurel, X. Differentiation of antique ceramics from the Raman spectra of their coloured glazes and paintings. J. Raman Spectrosc. 2001, 32, 351-360.

76. Eppler, R.; Eppler, D. Glazes and Glass Coatings; The American Ceramic Society: Westerville, OH, USA, 2000.

77. Meneret, L. Couleurs Céramiques. ENSCI Report; ENSCI: Sèvres, France, 1975.

78. Colomban, P. Secrets retrouvés du Lustre Abbasside. La Revue de la Céramique et du Verre, 2004, 139, 13-21. Available online: http://www.ladir.cnrs.fr/pages/colomban/Lustreceramique.pdf (accessed on 8th July 2013).

79. Colomban, P. The use of metal nanoparticles to produce yellow, red and iridescent colour, from Bronze Age to Present Times in Lustre pottery and glass: Solid state chemistry, spectroscopy and nanostructure. J. Nano Res. 2009, 8, 109-132.

80. Sciau, P. Nanoparticle in Ancient Materials, the Metallic Lustre of Medieval Ceramics. In The Delivery of Nanoparticles, Chapter: 25; InTech: Winchester, UK, 2012; doi:10.5772/34080.

81. Baroni, S. Restauration et Conservation des Tableaux-Manuel Pratique; CELIC: Paris, France, 1992.

82. Kendix, E.; Moscardi, G.; Mazzeo, R.; Baraldi, P.; Prati, S.; Joseph, E.; Capelli, S. Far infrared and Raman spectroscopy analysis of inorganic pigments. J. Raman Spectrosc. 2008, 39, 1104-1112.

83. Artioli, G.; Angelini, I.; Polla, A. Crystals and phase transitions in protohistoric glass materials. Phase Trans. 2008, 81, 233-252. 
84. Vandiver, P.; Kingery, W.D. Egyptian Faience: The first High-Tech Ceramic. In High Technology Ceramics -Past, Present, and Future. The Nature of Innovation and Change in Ceramic Technology; Kingery, W.D., Ed.; The American Ceramic Society: Westerville, OH, USA, 1986; Ceramic and Civilization Volume III, pp. 19-34.

85. Ellis, L.; Newman, R. The analyzis of glazed quartzite sculpture from Kerma, Capital of ancient Kush (Sudan). MRS Fall Mee. Proc. 2005, 852, OO7.3-OO7.10.

86. Angelini, I.; Artioli, G.; Bellintani, P.; Diella, V.; Gemmi, M.; Polla, A.; Rossi, A. Chemical analyses of bronze age glasses from Frattesina di Rovigo, northern Italy. J. Archaeol. Sci. 2004, 31, 1175-1184.

87. Brun, N.; Mazerolles, L.; Pernot, M. Microstructure of opaque red glass containing copper. J. Mater. Sci. Lett. 1991, 10, 1418-1420.

88. Nicholson, P.T. Glass-making and glass-working at Amarna: Some new work. J. Glass Stud. 1995, 37, 11-19.

89. Shortland, A.J.; Tite, M.S. The Interdependence of Glass and Vitreous Faience Production at Amarna. In Prehistory and History of Glassmaking Technology; McCray, P., Ed.; The American Ceramic Society: Westerville, OH, USA, 1998; Ceramics and Civilization Series Volume VIII; pp. 251-265.

90. Gratuze, B.; Soulier, I.; Barrandon, J.N.; Foy, D. De l'origine du cobalt dans les verres. Revue d'Archéomètrie 1992, 16, 97-108.

91. Gratuze, B.; Soulier, I.; Blet, M.; Vallauri, L. De l'origine du cobalt: Du verre à la céramique, Revue d'Archéomètrie 1996, 20, 77-94.

92. Sciau, P.; Relaix, S.; Kihn, Y.; Roucau, C. The role of microstructure, nanostructure and composition in the brilliant red slip of Roman terra sigillata pottery from southern Gaul. MRS Fall Meet. Proc. 2005, 852, 006.4.

93. Brill, R.H. Chemical Analyses of Early Glasses; The Corning Museum of glass: New York, NY, USA, 1999.

94. Colomban, P.; Calligaro, Th.; Vibert-Guigue, Cl.; Liem, N.Q.; Edwards, H.G.M. Accrochage des dorures sur les céramiques et tesselles anciennes. Revue d'Archéométrie-Archeosciences 2006, 29, 7-20.

95. Greiff, S.; Schuster, J. Technological study of enamelling on Roman glass: the nature of opacyfing, decolourising and fining agents used with the glass beakers from Lübsow (Lubieszewo, Poland). J. Cult. Herit. 2008, 9 Suppl., e27-e32.

96. West FitzHugh, E.; Zycherman, L.A. A purple Baryum copper silicate pigment from early China. J. Conserv. Stud. 1992, 37, 145-154.

97. Cheng, X.; Yin, X.; Ma, Y.; Lei, Y. Three fabricated pigments (Han purple, indigo and emerald green) in ancient Chinese artifacts studied by Raman microscopy, energy-dispersive X-ray spectrometry and polarized light microscopy. J. Raman Spectrosc. 2007, 38, 1274-1280.

98. Bouherour, S.; Berke, H.; Wiedemann, H.G. Ancient man-made copper silicate pigments studied by Raman microscopy. Chimia 2001, 55, 942-951. Berke, H.; Wiedemann, H.G. The chemistry and fabrication of anthropogenic pigments Chinese blue and purple in ancient China. EASTM 2000, 94-120. 
99. Bianchetti, P.; Talarico, F.; Vigliano, M.G.; Fuad Ali, M. Production and characterization of Egyptian Blue and green frit. J. Cult. Herit. 2000, 1, 179-188.

100. Burgio, L.; Clark, R.J.H. Comparative pigment analysis of six modern Egyptian papyri and an authentic one of the 13th century BC by Raman microscopy and other techniques. J. Raman Spectrosc. 2000, 31, 395-401.

101. Guy, J. Early ninth century Chinese export ceramics and the Persian Gulf connection: the Belitung shipwreck evidence, in Chine-Méditerranée, Routes et échanges de la céramique avant le XVIe siècle. Taoci,(Editions SFECO-Findalkly,Suilly-la-Tour, France) 2005, 4, 145-152.

102. Fukang, Z. The Origin and Development of Traditional Chinese Glazes and Decorative Ceramic Colors. In Ancient Technology to Modern Science; Kingery, W.D., Ed.; The American Ceramic Society: Westerville, OH, USA, 1984; Ceramic and Civilization Volume I.

103. Wood, N. Chinese Glazes: Their Origins, Chemistry and Recreation; A \& C Black Publishers Ltd: London, UK, 1999.

104. Soustiel, J. La Céramique Islamique-Le Guide du Connaisseur; Office du Livre: Paris, France, 1985.

105. Tite, M.; Pradell, T.; Shortland, A. Discovery, production and use of tin-based opacifiers in glasses, enamels and glazes from the late iron age onwards: A reassement. Archaeometry 2008, 50, 67-84.

106. Rubio, F.; Pérez-Villar, S.; Garrido, M.A.; Rubio, J.; Oteo, J.L. Application of gradient and confocal raman spectroscopy to analyze silver nanoparticle diffusion in medieval glasses. J. Nano Res. 2009, 8, 89-97.

107. Colomban, P.; Etcheverry, M.-P.; Asquier, M.; Bounichou, M.; Tournié, A. Raman identification of ancient stained glasses and their degree of deterioration. J. Raman Spectrosc. 2006, 37, 614626.

108. Colomban, P.; Tournié, A.; Ricciardi, P. Raman spectroscopy of copper nanoparticles-containing glass matrix: The ancient red stained-glass windows. J. Raman Spectrosc. 2009, 40, 1949-1955.

109. Kirmizi, B.; Colomban, P.; Blanc, M. On-site Analysis of Limoges enamels from $16^{\text {th }}$ to $19^{\text {th }}$ century. J. Raman Spectrosc. 2010, 41, 1240-1247.

110. Blanc, M. Emaux peints de Limoges, XVe-XVIIIe siècles - La collection du Musée des Arts décoratifs; Les arts décoratifs: Paris, France, 2011.

111. Kirmizi, B.; Colomban, P.; Quette, B. On-site analysis of Chinese cloisonné enamels from $15^{\text {th }}$ to $19^{\text {th }}$ century. J. Raman Spectrosc. 2010, 41, 780-790.

112. Ricciardi, P.; Colomban, P.; Tournié, A.; Milande, V. Non-destructive on-site identification of ancient glasses: Genuine artefacts, embellished pieces or forgeries? J. Raman Spectrosc. 2009, 40, 604-617.

113. Colomban, P.; Tournié, A.; Caggiani, M.C.; Paris, C. Pigments and enamelling/gilding technology of Mamluk mosque lamps and bottle. J. Raman Spectrosc. 2012, 43, 1975-1984.

114. Berrie, B.H.; Matthew, L.C. Material Innovation and Artistic Invention: New Materials and New Colors in Renaissance Venetian Paintings, in Scientific Examination of Art-Modern Techniques in Conservation and Analysis; The National Academies Press: Washington, DC, USA, 2005; pp. 12-26. 
115. Atasoy, N.; Raby, J. Iznik, the Pottery of Ottoman Turkey; Petsoupoulos, Y., Ed.; Alexandria Press: London, UK, 1989; pp. 50-73.

116. Goder, W.; Schulle, W.; Wagenbreth, O.; Walter, H. Mise au Point Technique du grès de Böttger et de la Porcelaine de Böttger. In Meissen, La Découverte de la Porcelaine Européenne en Saxe - J.F. Böttger 1709-1736; Pygmalion-Gérard Watelet: Paris, France, 1984; pp. 106-154.

117. Colomban, P.; Gouadec, G. The ideal ceramic fiber/oxide matrix composite: How to conciliate antagonist physical and chemical requirements? Ann. Chim. Sci. Matériaux 2005, 30, 673-688.

118. Bertran, H. Nouveau Manuel Complet de la Peinture sur Verre, sur Porcelaine et sur Email. Encyclopédie-Roret; Mulo, L., Ed.: Paris, France, 1913.

119. Kruger, P. Principles of Activation Analysis; Wiley Interscience: New York, NY, USA, 1971.

120. Pollard, A.M.; Heron, C. Archaeological Chemistr; Royal Society Chemistry Paperback: Cambridge, UK, 1996.

121. Janssens, K. Modern Methods for Analysing Archaeological and Historical Glass, 1st ed.; John Wiley \& Sons Ltd: Chichester, UK, 2012; Volume 2.

122. Fisher, A.; Goodall, P.; Hinds, M.W.; Nelms, S.N.; Penny, D.M. Atomic spectrometry update. Industrial analysis: Metals, chemicals and advanced materials. J. Anal. Atom. Spectrosc. 2003, 18, 1497-1528.

123. Falcone, R.; Renier, A.; Verita, M. Wavelength-dispersive x-ray fluorescence analysis of ancient glasses. Archaeometry 2002, 44, 531-542.

124. Mucha, H.-J.; Bartel, H.-G.; Dolata, J. Effects of Data Transformation on Cluster Analysis of Archaeometric Data. In Data Analysis, Machine Learning and Applications Studies in Classification, Data Analysis, and Knowledge Organization; Springer: Berlin, Germany, 2008; Book Series: Studies in Classification Data Analysis and Knowledge Organization, XI, pp. 681-688.

125. Michelaki, K.; Hancock, R.G.V. Chemistry versus Data dispersion: Is there a better way to assess and interpret archaeometric data? Archaeometry 2011, 53, 1259-1279.

126. Agha-Alidol, D.; Oliaiy, P.; Mohsenian, M.; Lamehi-Rachti, M.; Shokouhi, F. Provenance study of ancient Iranian luster pottery using PIXE multivariate statistical analysis. J. Cult. Herit. 2009, 10, 497-492.

127. Padeletti, G.; Fermo, P. A scientific approach to the attribution problem of renaissance ceramic productions based on chemical and mineralogical markers. Appl. Phys. A 2010, 100, 771-784.

128. Giussani, B.; Monticelli, D.; Rampazzi, L. Role of laser ablation-inductively coupled plasma-mass spectrometry in cultural heritage research: A review. Anal. Chim. Acta 2009, 635, 6-21.

129. Zachariadis, G.; Dimitrakoudi, E.; Anthemidis, A.; Stratis, J. Optimized microwave-assisted decomposition method for multi-element analysis of glass standard reference material and ancient glass specimens by inductively coupled plasma atomic emission spectrometry. Talanta 2006, 68, 1448-1456.

130. Giakoumaki, A.; Melessanaki, K.; Anglos, D. Laser-induced breakdown spectroscopy (LIBS) in archaeological science-applications and prospects. Anal. Bioanal. Chem. 2007, 387, 749-760.

131. Yoon, Y.; Kim, T.; Yang, M.; Lee, K.; Lee, G. Quantitative analysis of pottery glaze by laser induced breakdown spectroscopy. Microchem. J. 2001, 68, 251-256. 
132. Clark, R.J.H. Pigment identification by spectroscopic means: An arts/science interface. Compte-Rendus Chim. 2002, 5, 7-20.

133. Colao, F.; Fantoni, R.; Lazic, V.; Spizzichino, V. Laser-induced breakdown spectroscopy for semi-quantitative and quantitative analyses of artworks-Application on multi-layered ceramics and copper based alloys. Spectrochim. Acta B 2002, 57, 1219-1234.

134. Dran, J.C; Salomon, J.; Calligaro, T.; Walter, P. Review of accelerator gadgets for art and archaeology. Nuclear Instr. Methods Phys. Res. Sect. B Phys. Inter. Mater. Atom. 2004, 226, 29-37.

135. Enguita, O.; Fernandez-Jimenez, M.T.; Garcia, G.; Climent-Font, A.; Calderon, T.; Grime, G.W. The new external microbeam facility at the $5 \mathrm{MV}$ Tandetron accelerator laboratory in Madrid: Beam characterisation and first results, Nuclear Instr. Methods Phys. Res. Sect. B Phys. Inter. Mater. Atom. 2004, 219, 384-388.

136. Denker, A.; Hahn, O.; Kanngiesser, B.; Malzer, W.; Merchel, S.; Radtke, M.; Rohrs, S. Chemistry of arts-Non-destructive analysis of artistic and cultural heritage objects. MaterialPrufung 2003, 45, 485-503.

137. Mando, P.A.; Fedi, M.E.; Grassi, N. The present role of small particle accelerators for the study of Cultural Heritage. Eur. Phys. J. Plus 2011, 126, doi: 0.1140/epjp/i2011-11041-9.

138. Salvado, N.; Buti, S.; Tobin, M.J.; Pantos, E.; Prag, A.J.N.W.; Pradell, T. Advantages of the use of SR-FT-IR microspectroscopy: Applications to cultural heritage. Anal. Chem. 2005, 77, 3444-3451.

139. Janssens, K.; Vittiglio, G.; Deraedt, I.; Aerts, A.; Vekemans, B.; Vincze, L.; Wei, F.; Deryck, I.; Schalm, O.; Adams, F.; et al. Use of microscopic XRF for non-destructive analysis in art and archaeometry. X-ray Spectrom. 2000, 29, 73-91.

140. Creagh, D.C. The characterization of artefacts of cultural heritage significance using physical techniques. Radiat. Phys. Chem. 2005, 74, 426-442.

141. Moioli, P.; Seccaroni, C. Analysis of art objects using a portable X-ray fluorescence spectrometer. X-ray Spectrom. 2000, 29, 48-52.

142. Papadopoulou, D.N.; Zachariadis, G.A.; Anthemidis, A.N.; Tsirliganis, N.C.; Stratis, J.A. Development and optimisation of a portable micro-XRF method for in situ multi-element analysis of ancient ceramics. Talanta 2006, 68, 1692-1699.

143. Nuevo, M.J.; Sanchez, A.M. Application of XRF spectrometry to the study of pigments in glazed ceramic pots. Appl. Rad. Isotopes 2011, 69, 574-579.

144. Colomban, P.; Tournié, A.; Maucuer, M.; Meynard, P. On-site Raman and XRF analysis of Japanese/Chinese Bronze/Brass Patina-The search of specific Raman signatures. J. Raman Spectrosc. 2012, 43, 799-808.

145. Ferretti, M.; Cristoforetti, G.; Legnaloll, S.; Palleschi, V.; Salvetti, A.; Togrioni, E.; Console, E.; Palaia, P.In situ study of the Porticello Bronzes by portable X-Ray fluorescence and laser induced breakdown spectroscopy. Spectrochim. Acta B Atom. Spectrosc. 2007, 62, 1512-1518.

146. Brai, M.; Gennaro, G.; Schillaci, T.; Tranchina, L.Double pulse laser induced breakdown spectroscop applied to natural and artificial materials from cultural heritage - A comparison with micro-X-Ray fluorescence analyses. Spectrochim. Acta B Atom. Spectrosc. 2009, 64, 1119-1127. 
147. Turrell, G.; Corset, J. Raman Microscopy-Developments and Applications; Academic Press Ltd: San-Diego, CA, USA, 1976.

148. Long, D.A. Raman Spectroscopy; McGraw-Hill International Book Cy: New-York, NY, USA, 1977.

149. Gouadec, G.; Colomban, P. Raman study of Nanomaterials: How spectra related to disorder, particle size and mechanical properties. Progr. Cryst. Growth Charact. Mater. 2007, 53, 1-56.

150. Brillouin, L. Diffusion of light and x-rays by a transparent homogeneous body. The influence of thermal agitation. Ann. Phys. 1922, 17, 88-95; ibidem, Regarding the propagation of light in a dispersive medium. Comptes-Rendus Acad. Sci. 1921, 173, 1167-1170.

151. Smekal, A. The quantum, theory of dispersion. Naturwissenschaften 1923, 11, 873-878; ibidem, Contribution to my work "Remarks on the quantisation of non determined periodic system. Zeitschrift fur Physick 1923, 15, 58-60.

152. Cabannes, J. New optical phenomenon; pulsations produced when anisotropic molecules in rotation and vibration diffuse visible and ultra-violet light. Comptes-Rendus Acad. Sci. 1927, 185, 1026-1028.

153. Rocard, Y. New diffused radiations. Comptes-Rendus de l'Acad. Sci. 1928, 186, 1107-1115.

154. Landsberg, G.; Mandelstam, L. A novel effect of light scattering in crystals. Naturwissenschaften 1928, 16, 557-558. ibidem, Light scattering in crystals, Zeitschrift fur Physik 1928, 50, 769-780. Pringsheim, P.; Rosen, B.; About the Raman Effect, Zeitschrift fur Physik 1928, 50, 741-755.

155. Raman, C.V.; Krishnan, K.S. A new type of secondary radiation. Nature 1928, 121, 501-516.

156. Colomban P.; Tournié, A. On-site raman identification and dating of ancient/modern stained glasses at the sainte-chapelle. J. Cult. Herit. 2007, 8, 242-256.

157. Mancini, D.; Tournié, A.; Caggiani, M.-C.; Colomban, P. Testing of Raman spectroscopy as a non-invasive tool for the investigation of glass-protected miniature portraits. J. Raman Spectrosc. 2012, 43, 294-302.

158. Colomban, P.; Caggiani, M.-C. Testing of Raman spectroscopy as a non-invasive tool for the investigation of glass-protected pastels. J. Raman Spectrosc. 2011, 42, 790-798.

159. Tournié, A.; Prinsloo, L.C.; Paris, C.; Colomban, P.; Smith, B. The first in-situ Raman spectroscopic study of Bushman/San rock art in South Africa; procedures and preliminary results. J. Raman Spectrosc. 2011, 42, 399-406.

160. Colomban, P. Polymerisation degree and raman identification of ancient glasses used for jewellery, ceramics enamels and mosaics. J. Non-Crystall. Solids 2003, 323, 180-187.

161. Colomban, P.; Paulsen, O. Raman determination of the structure and composition of glazes. J. Am. Ceram. Soc. 2005, 88, 390-395.

162. Colomban, P.; Tournié, A.; Bellot-Gurlet, L. Raman Identification of glassy silicates used in ceramic, glass and jewellry: A tentative differentiation guide. J. Raman Spectrosc. 2006, 37, 841-852.

163. Colomban, P. On-site Raman identification and dating of ancient glasses: Procedures and tools. J. Cult. Herit. 2008, 9 Suppl., e55-e60.

164. Colomban, P.; Prinsloo, L. Optical Spectroscopy of Silicates and Glasses. In Spectroscopic Properties of Inorganic and Organometallic Compounds; Yarwood, J., Douthwaite, R., 
Duckett, S.B., Eds.; RSC Publishing: Cambridge, UK, The Royal Society of Chemistry, 2009. pp. 128-149.

165. Bell, I.M.; Clark, R.J.H.; Gibbs, P.J. Raman spectroscopic library of natural an synthetic pigments (pre- 1850 AD). Spectrochim. Acta Part A 1997, 53, 2159-2179.

166. Griffith, W.P. Raman Spectroscopy of Terrestrial Minerals. In Infrared and Raman Spectroscopy of Lunar and Terrestrial Minerals; Karr, C., Ed.; Academic Press: New York, NY, USA, 1975; Chapter 12.

167. Nakamoto, K. Infrared \& Raman Spectra of Inorganic and Coordination Compounds: Theory and Application in Inorganic Chemistry; J. Wiley \& Sons: Chichester, UK, 1997.

168. Maestrati, R. Contribution à l'Edification du Catalogue Raman des Gemmes, Diplôme de Gemmologie, Université de Nantes, Nantes, France, 1989.

169. Pinet, M.; Smith, D.C.; Lasnier, B. Utilité de la microsonde Raman pour l'identification non-destructive des gemmes, La Microsonde Raman en Géologie, $N^{\circ}$ Hors-Série, Revue de Gemmologie, Paris, UK, 1992, Juin, 11-30.

170. Information on minerals. Available online: http://minerals.gps.caltech.edu/files/raman (accessed on 4th February 2012); http://www.ens-lyon.fr/LST/Raman/index.php (accessed on 4th February 2012); http://www.aist.go.jp/RIODB/rasmin/E_index.htm; http://rruff.geo.arizona.edu/rruff/ (accessed on 4th February 2012); http://www.irug.org/ed2k/search.asp; http://www.fis.unipr.it/phevix/ramandb.html (accessed on 4th February 2012); Information on pigments. Available online: http://srv.chim.unifi.it/raman/ (accessed on 4th February 2012); http://www.chem.ucl.ac.uk/resources/raman/index.html (accessed on 4th February 2012).

171. Clark, R.J.H..The scientific investigation of artwork and archaeological artefacts: Raman microscopy as a structural, analytical and forensic tool, . Appl. Phys. A-Mater. Sci. \& Process. 2007, 89, 833-840.

172. Burgio, L.; Clark, R.J.H. Library of FT-Raman spectra of pigments, minerals, pigment media and varnishes, and supplement to existing library of Raman spectra of pigments with visible excitation. Spectrochim. Acta Part A 2001, 57, 1491-1521.

173. Williams, R.S. On-site non-destructive ID-IR spectroscopy of plastic in museum objects using a portable FT-IR Spectrometer with fibre-optic probe, materials issues in art \& archaeology. MRS Proc. 1997, 462, 25-30.

174. Logan, L.L.; Hunt, G.R.; Salisbury, J.W. The Use of Mid-infrared Spectroscopy in Remote Sensing of Space Targets. In Infrared and Raman Spectroscopy of Lunar and Terrestrial Minerals; Karr, C., Jr., Ed.; Academic Press: New York, NY, USA, 1975; pp. 117-142.

175. Adams, J.B. Interpretation of Visible and Near Infrared Diffuse Reflectance Spectra of Pyroxenes and other Rock Forming Minerals. In Infrared and Raman Spectroscopy of Lunar and Terrestrial Minerals; Karr, C., Jr., Ed.; Academic Press: New York, NY, USA, 1975; pp. 91-116.

176. Munier, P. Technologie des Faïences; Gauthier-Villars: Paris, France, 1957.

177. Liem, N.Q.; Colomban, P.; Sagon, G.; Tinh, H.X.; Hoanh, T.B. Microstructure, composition and processing of the $15^{\text {th }}$ century vietnamese porcelains and celadons. J. Cult. Herit. 2003, 4, 187197. 
178. Liem, N.Q.; Thanh, N.T.; Colomban, P. Reliability of raman microspectrometry in analysis of ancient ceramics: The case of ancient vietnamese porcelains and celadon glazes. J. Raman Spectrosc. 2002, 33, 287-294.

179. Colomban, P.; Milande, V. On Site Analysis of the earliest known Meissen Porcelain and Stoneware. J. Raman Spectrosc. 2006, 37, 606-613.

180. Ricciardi, P.; Colomban, P.; Tournié, A.; Macchiarola, M.; Ayed, N. A non-invasive study of Roman Age mosaic glass tesserae by means of Raman spectroscopy. J. Archaeol. Sci. 2009, 36, 2551-2559.

181. Prinsloo, L.C.; Tournié, A.; Colomban, P. A Raman spectroscopic study of the glass trade beads excavated at Mapungubwe hill and K2, two important archaeological sites in southern Africa, raises questions about the last occupation date of the hill. J. Archaeol. Sci. 2011, 38, 3264-3277.

182. Prinsloo, L.C.; Tournié, A.; Colomban, P. Raman classification of the glass beads excavated on Mapungubwe hill and K2, two archaeological sites in South Africa. J. Raman Spectrosc. 2012, $44,532-542$.

183. Andrikopoulos, K.S.; Daniilia, S.; Roussel, B.; Janssens, K. In vitro validation of a mobile Raman-XRF microanalytical instrument's capabilities on the diagnosis of Byzantine icons. J. Raman Spectrosc. 2006, 37, 1026-1034.

184. Baraldi, P.; Fagnano, C.; Bensi, P. Raman study of a "Tabula Colorum Physiologica" in a 1686 peinted journal. J. Raman Spectrosc. 2006, 37, 1104-1110.

185. Benquerenca, M.-J.; Mendes, N.F.C.; Castelluci, E.; Gaspar, V.M.F.; Gil, F.P.S.C. Micro-Raman spectroscopy analysis of 16th century Portuguese Ferreirim Masters oil paintings. J. Raman Spectrosc. 2009, 40, 2135-2143.

186. De Waal, D. Micro-Raman and portable Raman spectroscopic investigation of blue pigments in selected Delft plates (17-20th Century). J. Raman Spectrosc. 2009, 40, 2162-2170.

187. Bouchard, M.; Gambardella, A. Raman microscopy study of synthetic cobalt blue spinels used in the field of art. J. Raman Spectrosc. 2009, 41, 1477-1485.

188. Colomban, P.; Sagon, G.; Huy, L.Q.; Liem, N.Q.; Mazerolles, L. Vietnames ( $15^{\text {th }}$ century) Blueand-White Tam Tai and Lustre Porcelains/Stonewares: Glaze composition and decoration techniques. Archaeometry 2004, 46, 125-136.

189. Colomban, P. Les Routes du Lapis lazuli; Taoci (Editions SFECO-Findalkly, Suilly-la-Tour, France) 2005, 4, 145-154.

190. Colomban, P. Lapis lazuli as unexpected pigment in Iranian Lâjvardina ceramics. J. Raman Spectrosc. 2003, 34, 420-423.

191. Buffon (Comte de), Histoire Naturelle des Minéraux, Tome Septième; Imprimerie Royale: Paris, France, 1787; pp. 251-259.

192. Lo Giudice, A.; Re, A.; Calusi, S.; Giuntini, L.; Massi, M.; Olivero, P.; Pratesi, G.; Albonico, M.; Conz, E. Multitechnique characterization of lapis lazuli for provenance study. Anal. Bioanal. Chem. 2009, 395, 2211-2217.

193. Clark, R.J.H.; Curri, M.L.; Laganara, C. Raman microscopy: The identification of lapis lazuli on medieval pottery fragments from the south of Italy. Spectrochim. Acta Part A 1997, 53, 597-603. 
194. Catalano, I.M.; Genga, A.; Laganara, C.; Laviano, R.; Mangone, A.; Marano, D.; Traini, A. Lapis lazuli usage for blue decoration of polychrome painted glazed pottery: A recurrent technology during the Middle Ages in Apulia (Southern Italy). J. Archaeol. Sci. 2007, 34, 503-511.

195. Mangone, A.; Caggiani, M.C.; Giannossa, L.C.; Laviano, R.; Mutino, S.; Sabbatini, L.; Traini, A. Islamic Gilded and Enamelled Glasses from Melfi (Southern Italy): An Archaeometric Study. In Proceedings of the 5th International Congress "Science and Technology for the Safeguard of Cultural Heritage in the Mediterranean Basin", Istanbul, Turkey, 22-25 November 2011.

196. Ward, R. Gilded and Enamelled Glass from the Middle East; British Museum Press: London, UK, 1998.

197. Freestone, I.C.; Stapleton, C.P. Composition and Technology of Islamic enamelled glass of the $13-14^{\text {th }}$ centuries (ch 24) in Gilded and Enamelled Glass from the Middle East, Ward, R., Ed.; British Museum Press: London, UK, 1998.

198. Caggiani, M.C.; Colomban, P.; Mangone, A.; Cambon, P. Mobile Raman spectroscopy analysis of ancient enamelled glass masterpieces. Analyst submitted.

199. Clark, R.J.H.Raman microscopy as structural and analytical tool in the field of art and archaeology. J. Mol. Struct. 2007, 834, 74-80.

200. Perreira, M.; de Lacerda-Aroso, T.; Gomes, M.J.M.; Mata, A.; Alves, L.C.; Colomban, P. Ancient portuguese ceramic wall tiles («Ajulejos »): Characterization of the glaze and ceramic pigments. J. Nano Res. 2009, 8, 79-88.

201. Colomban, P.; Schreiber, H.; Raman signature modification induced by copper nanoparticles in silicate glass. J. Raman Spectrosc. 2005, 36, 884-890.

202. Colomban, P. Gel technology in ceramics, glass-ceramics and ceramic-ceramic composites. Ceramics Int. 1989, 15, 23-50.

203. Colomban, P.; March, G.; Mazerolles, L.; Karmous, T.; Ayed, N.; Ennabli, A.; Slim, H. Raman identification of materials used for jewelry and mosaic in ifriqiya. J. Raman Spectrosc. 2003, 34, $205-215$.

204. Bénard, J.; Dragesco, B. Bernard Perrot et les verreries royales du Duché d'Orléans, 1662-1754; Editions des amis du musée d'Orléans: Orléans, France, 1989; pp. 55-66.

205. Barrelet, J. Le Verre en France, Cahiers de la Céramique, du Verre et des Arts du feu, 1964, 36, 254-270.

206. Vaughan, A. Raman nanotechnology-The lycurgus cup. IEE Electr. Insul. Mag. 2008, 24, 4-8.

207. Freestone, I.; Meeks, N.; Sax, M.; Higgitt, C. The lycurgus cup-A Roman nanotechnology. Gold Bull. 2007, 40, 270-277.

208. De Lucas, M.C.; Moncada, F.; Rosen, J. Micro-Raman study of red decorations in French faiences of the 18th and 19th centuries. J. Raman Spectrosc. 2006, 37, 1154-1159.

209. Caggiani, M.C.; Colomban, P. Raman identification of strongly absorbing phases: The ceramic black pigments. J. Raman Spectrosc. 2011, 42, 839-843.

210. Girel, J. Les noirs des Song: hypothèses et expériences. Lett. SFECO 2002, 6, 31-35. Available online: http://www.ladir.cnrs.fr/pages/colomban/SF6imagine.pdf (accessed on 4th February 2013). 
211. Perez, J.M.; Esteve-Tebar, R. Pigment identification in Greek pottery by Raman microspectroscopy. Archaeometry 2004, 46, 607-614.

212. Mirti, P.; Gulmini, M.; Perardi, A.; Davit, P.; Elia, D. Technology of production of red figure pottery from Attic and southern Italian workshops. Anal. Bioanal. Chem. 2004, 380, 712-718.

213. Mangone, A.; de Benedetto, G.E.; Fico, D.; Giannossa, L.C.; Laviano, R.; Sabbatini, L.; van der Werf, I.D.; Traini, A. A multianalytical study of archaeological faience from the Vesuvian area as a valid tool to investigate provenance and technological features. New J. Chem. 2011, 35, 2860-2868.

(C) 2013 by the authors; licensee MDPI, Basel, Switzerland. This article is an open access article distributed under the terms and conditions of the Creative Commons Attribution license (http://creativecommons.org/licenses/by/3.0/). 